\title{
ZESPÓŁ DEWOCJONALIÓW Z WYKOPALISK NA CMENTARZU PRZY KOŚCIELE PW. ŚW. BARBARY NA STARYM MIEŚCIE W CZECSTOCHOWIE
}

SŁowA KLUCzowe: cmentarz, grób, dewocjonalia, medaliki, krzyżyk KEYwords: cemetery, grave, devotional items, medallions, crosses

W maju 2015 r. podczas nadzoru archeologicznego pełnionego przy robotach ziemnych związanych z przebudową ul. Nadrzecznej i placu Bohaterów Getta w Częstochowie, w rejonie skrzyżowania z ul. Jaskrowską, w wykopie liniowym zidentyfikowano ludzkie szczątki kostne (ryc. 1). Teren odkrycia znalazł się w obrębie stanowiska archeologicznego nr 49 (AZP 86-48/1) Częstochowa Stare Miasto.

W miejscu wystąpienia materiału kostnego podjęto badania archeologiczne, które w związku z odkryciem dalszych, regularnych jam grobowych oraz fragmentów architektury, objęły większy obszar i przekształciły się w regularne badania wykopaliskowe, trwające do końca czerwca 2015 r. Przebadano powierzchnię około $550 \mathrm{~m}^{2}$, odsłaniając relikty obiektu murowanego w postaci fundamentów wykonanych z łamanego kamienia wapiennego zespolonego zaprawą wapienną (obiekt 1), pozostałości cmentarza przykościelnego, a także relikty kolejnego obiektu, w postaci fundamentów piwnicy, wykonanych z łamanego kamienia wapiennego zespolonego gliną, prawdopodobnie pierwotnie na powierzchni drewnianego (obiekt 2). Odkopano także fundamenty architektury XIX i XX-wiecznej - pierzei wschodniej ul. Nadrzecznej (ryc. 2). W trakcie badań cmentarza między grobami odkryto skarb: 95 srebrnych monet z końca XVI i początku XVII w. (Młodkowska-Przepiórowska 2015: 1).

Przeprowadzona, już w pierwszych dniach badań, kwerenda historyczna wstępnie wykazała, że obiekt w postaci fundamentów wykonanych z łamanego kamienia wapiennego zespolonego zaprawą wapienną, to prawdopodobnie relikt funkcjonującego do XIX w. kościoła pw. św. Barbary, wokół którego znaj- 


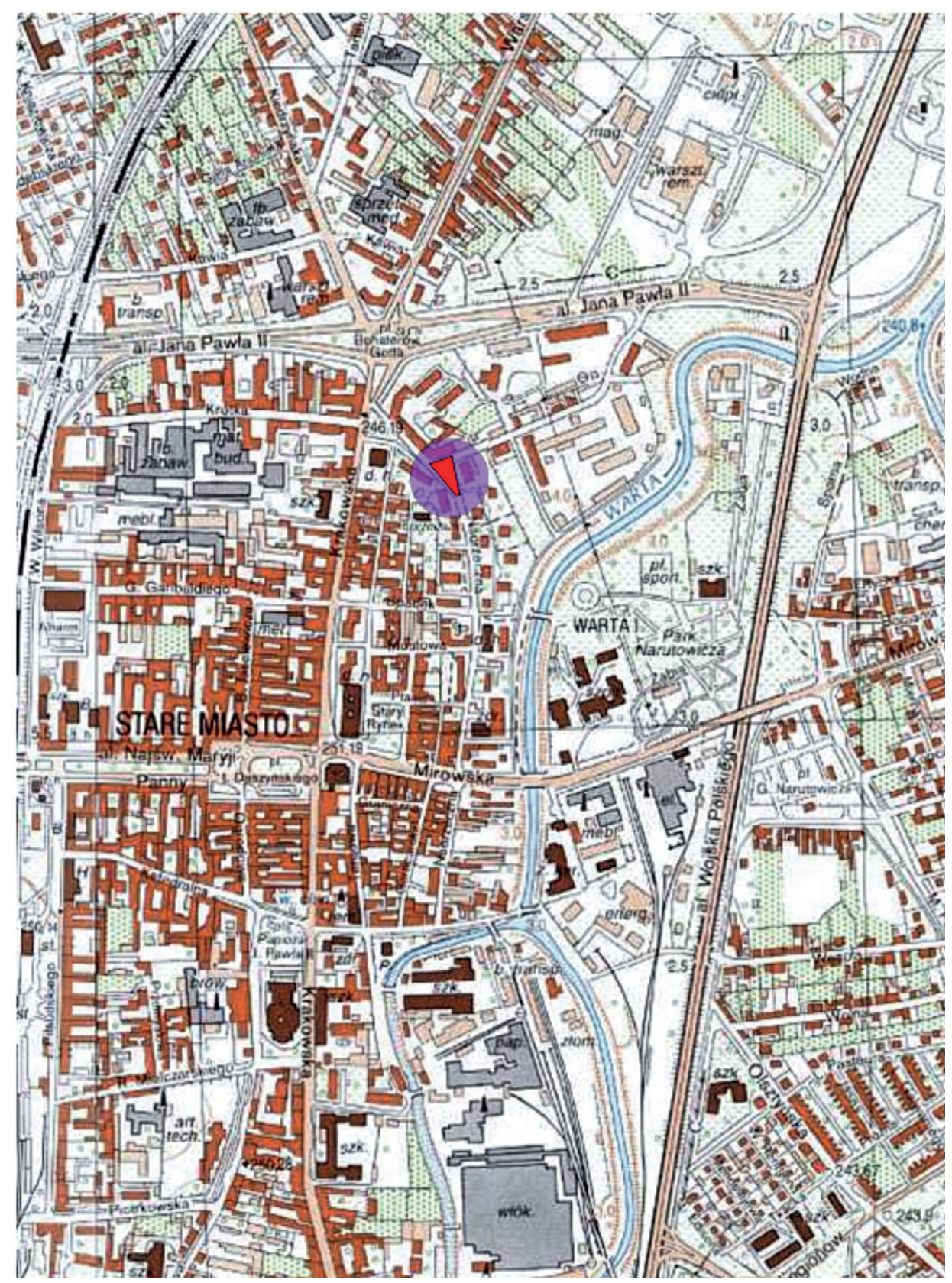

Ryc. 1. Częstochowa Stare Miasto, stan. 49 (AZP 86-48/1), ul. Nadrzeczna/Jaskrowska. Lokalizacja fragmentu stanowiska 49 z odkrytym kościołem pw. św. Barbary i cmentarzem przykościelnym. Skala 1:5000 (http://mapy.geoportal.gov.pl/imap/?gpmap=gp, dostęp 18.10.2018). 


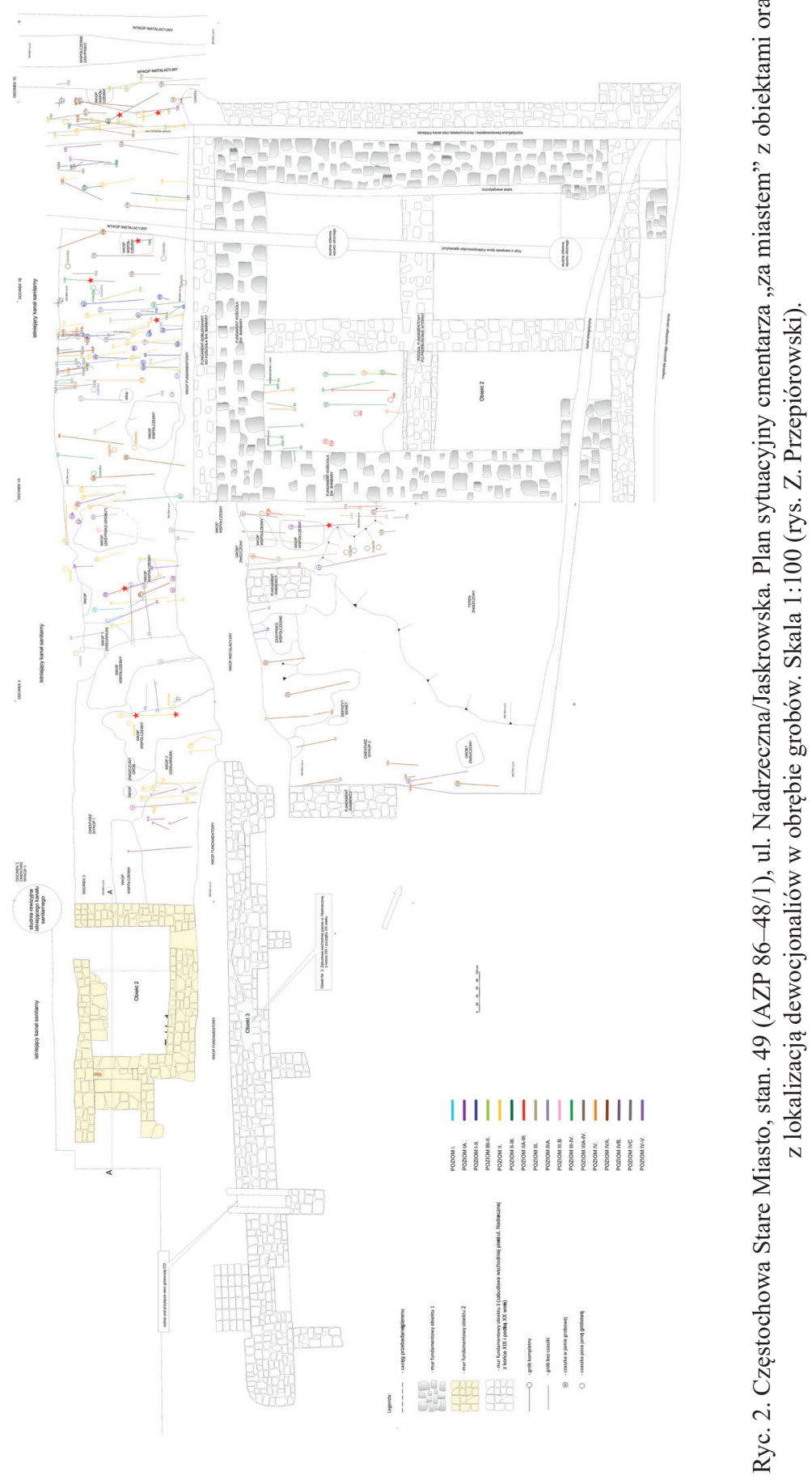


dował się cmentarz przykościelny zwany w źródłach historycznych „cmentarzem za miastem" ". Historycy lokowali świątynię w różnych miejscach. Stefan Krakowski widział ją za mostem, u wylotu „drogi krakowskiej”. Juliusz Braun wskazywał na budynek sakralny w północnej części miasta widoczny w panoramie Częstochowy na sztychu Jana Aleksandra Gorczyna przedstawiającym oblężenie Jasnej Góry przez Szwedów w 1655 r. ${ }^{2}$ Jadwiga Borowska-Antoniewicz poddała tę ostatnią lokalizację w wątpliwość, z powodu braku mostu w tym miejscu. Badaczka umiejscawiała kaplicę na przedmieściu Zawodzie, u wylotu ul. Mostowej, podobnie jak Jerzy Rajman (Borowska-Antoniewicz 2002: 470).

Po zgromadzeniu funkcjonujących w literaturze i cytowanych przez historyków źródeł dotyczących kościoła pw. św. Barbary, interpretacja odkrytych obiektów: kamiennego i prawdopodobnie drewnianego, nieco się skomplikowała. Źródła wzmiankują o istnieniu w okolicy obecnego placu Bohaterów Getta kościoła pw. św. Barbary, który miał zostać ufundowany w 1572 r. przez Wojciecha Siekańczyka, mieszczanina częstochowskiego. Wspomina go akt wizytacji z roku 1598, jako „budynek dość dobrze zbudowany z uposażeniem, który w ciągu najbliższych lat do wojny szwedzkiej zyskał kilka następnych fundacji” (Zbudniewek 2002: 236). $\mathrm{W}$ innym miejscu ten sam autor dodaje, że (Zbudniewek 2002: 207):

w średniowiecznej Częstochowie rozwijał się poza Jasną Górą drugi ośrodek kościelny w okolicach dzisiejszego kościoła pw. św. Zygmunta i, według dużego prawdopodobieństwa już we wczesnym okresie chrześcijaństwa w Polsce istniała w pobliżu obecnego placu Bohaterów Getta mała kaplica.

Kolejna informacja mówi o dwóch kaplicach pw. św. Barbary pod miastem, przy jednej z nich w roku 1572 odnotowano szpital - przytułek. Opisano ją w roku 1598, jako drewnianą i niekonsekrowaną (Rajman 2002: 173). W źródłach, wymiennie stosowane są, w stosunku do tego obiektu, określenia kościół/ kapliczka.

Lokalizację kościoła pw. św. Barbary wskazuje szereg przedstawień ikonograficznych i danych kartograficznych. Najlepiej prezentuje się na sztychu według miedziorytu wyżej wspomnianego J.A. Gorczyna. Obiekt ten jest zaznaczony także na mapie z 1748 r., przerysowanej w 1889 r. $^{3}$, następnie na planie miasta Częstochowy z 1823 r. oraz na planie parafii pw. św. Zygmunta z roku 1827. W tym miejscu znajduje się również w dokumentacji geodezyjno-karto-

${ }^{1} \mathrm{~W}$ tym miejscu pragnę podziękować Panu dr. Juliuszowi Sętowskiemu z Muzeum Częstochowskiego za cenną wskazówkę w rozpoznaniu obiektu.

${ }^{2}$ Miedzioryt Jana Aleksandra Gorczyna przedstawiający oblężenie Jasnej Góry przez Szwedów w 1655 r. (ze zbiorów Muzeum Narodowego w Krakowie, Gabinet rycin).

${ }^{3}$ Mapa ze zbiorów Jasnej Góry, niepublikowana. Dziękuję oj. Melchiorowi Królikowi za jej udostępnienie. 
graficznej powstałej w latach dwudziestych XIX w., sporządzonej przez geometrę inż. Jana Bernharda (Szymański 1965: 10). Najnowsze, wnikliwe badania historyczne, dotyczące przytułku przy kościele św. Barbary, lokują go w tym samym miejscu, co źródła ikonograficzne i kartograficzne (Szklarz-Habrowski 2018: 61).

Początki świątyni i cmentarza są niejasne, a dalsze ich losy jedynie wzmiankowane w źródłach. Od 1802 r. kościół służył do nabożeństw protestantom, następnie zapomniany, stopniowo zmieniał się $\mathrm{w}$ ruinę. Na jego fundamencie w XIX w. postawiono dom murowany, pierwszy w pierzei wschodniej ul. Nadrzecznej od strony północnej, którego zręby odsłonięto w trakcie badań wykopaliskowych. W XX w. teren ten znalazł się w obrębie częstochowskiego getta.

Odkrycia archeologiczne dokonane w 2015 r., wniosły nowe fakty do historii kościoła/kapliczki pw. św. Barbary. Zaobserwowano, że fundamenty murowanego obiektu 1, zostały postawione na istniejącym już cmentarzu, przecinając i niszcząc groby, co oznacza, że w czasie jego budowy cmentarz już istniał. Sporą niespodzianką okazał się obiekt $\mathrm{z}$ fundamentem piwnicy wykonanej z łamanego kamienia wapiennego zespolonego gliną (obiekt 2), który znajdował się w części południowo-zachodniej cmentarza. W jego najbliższej okolicy odkryto od strony północnej groby usytuowane na osi północ - południe zalegające pod obiektami położonymi wzdłuż osi wschód - zachód. Obiekt 2 znajdował się pod ul. Nadrzeczną, którą po raz pierwszy zaznaczono na planie z 1748 r. Interpretacja odkrytych, w czasie prac archeologicznych, obiektów jest przedmiotem trwających badań historycznych.

Analizy antropologiczne wykonane w trakcie prac archeologicznych na cmentarzu przykościelnym wykazały, że szacowana liczba osób pochowanych na terenie objętym badaniami (5,5 ara) wynosiła 1134 osoby ${ }^{4}$. Tak duża ilość grobów, świadczy o długim użytkowaniu cmentarza. Większość z nich zniszczono już w trakcie jego funkcjonowania, przy zakładaniu nowych pochówków. Dalsza destrukcja cmentarza nastąpiła przy pracach ziemnych związanych z budową kanalizacji sanitarnej w 1923 r. i deszczowej na przełomie lat 60. i 70. XX w.

Większość grobów była pozbawiona jakiegokolwiek wyposażenia. Przy nielicznych szczątkach zmarłych znaleziono paciorki różańców, medaliki, krzyżyki, pojedyncze szklane koraliki, guziki żelazne, brązowe i kościane, monety, haftkę, klamry, fragmenty sukna oraz ozdób tekstylnych i pasmanteryjnych. W drewnianych pozostałościach trumien tkwiły gwoździe, które występowały także luzem. W zasypiskach jam grobowych znajdowano pojedyncze ułamki ceramiki naczyniowej z okresu nowożytnego. Poza grobami zalegały także luźno

\footnotetext{
${ }^{4}$ Analizę antropologiczną pozyskanych materiałów kostnych wykonała dr hab. Anita Szczepanek.
} 
rozrzucone pojedyncze przedmioty, pochodzące prawdopodobnie ze zniszczonych pochówków (np. pierścionek, obrączki, monety).

Badania archeologiczne nie dały odpowiedzi na pytanie, kiedy cmentarz przy kościele św. Barbary został założony. Nie udało się również ustalić jego zasięgu. Prace objęły jedynie fragment nekropolii w obrębie inwestycji, w części południowej i zachodniej. Nadzór archeologiczny prowadzony poza terenem poddanym badaniom wykopaliskowym, wzdłuż ul. Nadrzecznej wykazał, że cmentarz znajdował się także od strony północnej kościoła i dalej na zachód, gdzie sięgał prawdopodobnie poza teren zniszczony mediami i wchodził pod pierwszą od zachodu kamienicę przy ul. Jaskrowskiej.

Cmentarz „za miastem” był miejscem pochówku nie tylko dla mieszkańców Częstochowy, ale i dla pensjonariuszy szpitala - przytułku, wśród których byli zapewne pielgrzymi. W czasach, gdy kościół wraz z cmentarzem został oddany zaborcom, służył jako miejsce spoczynku protestantów - żołnierzy austriackich.

Wśród zabytków ruchomych znalezionych na cmentarzu przykościelnym „za miastem”, przy kościele pw. św. Barbary, na szczególną uwagę zasługuje zbiór dewocjonaliów. Stanowi on jedyną, jak do tej pory opracowaną, historyczną kolekcję pochodzącą z terenu Częstochowy z wykopalisk archeologicznych ${ }^{5}$. Inny zbiór dewocjonaliów, pozyskany w trakcie badań wykopaliskowych przy parafii św. Zygmunta w 2012 r., jest w trakcie opracowania, w tym momencie jedynie wzmiankowany w sprawozdaniu z badań wykopaliskowych (Marek i in. 2014: 203-204).

\section{KaTALOG DEWOCJONALIÓW}

\section{Medalik lany dwustronny. Nr inwentarza polowego 49/2015.}

Opis: medalik owalnego kształtu o wymiarach 2,2 x 2,4 cm i grubości około $1,5 \mathrm{~mm}$. Posiadał owalne uszko do zawieszania o wysokości $8 \mathrm{~mm}$, uformowane węższą stroną do płaszczyzny awersu i rewersu. W górnej części uszka widoczne ślady obróbki - piłowania, w celu jego spłaszczenia. W uszku znajduje się otwór o średnicy około $1 \mathrm{~mm}$. Medalik posiada wyraźny relief plastyczny. Został odlany ze stopu metali kolorowych. Jest dobrze zachowany i czytelny, oddaje szczegóły przedstawień.

Treść ikonograficzno-kultowa: na awersie (dalej: Av) wizerunek św. Jana Chrzciciela młodzieńca - popiersie z profilu zwrócone w prawo. Święty z głową lekko uniesioną ku górze, $\mathrm{z}$ wydatnym nosem i uśmiechem na twarzy, o ramię prawe opiera krzyż opleciony wstęgą (banderolą). Na głowie pukle kręconych, ładnie wymodelowanych włosów. Na wysokości wyraźnie ukształtowanej, smu-

${ }^{5} \mathrm{~W}$ tym miejscu pragnę gorąco podziękować Pani mgr Barbarze Chudzińskiej, za pomoc w odczytaniu niektórych napisów i symboli. 
kłej dłoni, znajduje się głowa baranka (widoczne runo i róg). Po lewej stronie medalika napis wzdłuż otoku S[ANCTVS] IOANNES [B?]A[PTISTA].

Na rewersie (dalej: Rv) znajduje się klasyczne przedstawienie św. Mikołaja w stroju biskupim - pełna postać na wprost. Na ornacie wypukły deseń, pośrodku paliusz (racjonał), a na nim trzy krzyże w pionie. Wokół głowy kolista aureola. W lewej ręce święty trzyma otwartą księgę. Na jej górnym grzbiecie spoczywają trzy kule ułożone w stos (mogą to być także jabłka). Prawa dłoń wzniesiona w geście błogosławieństwa(?). Przy lewej nodze świętego stoi cebrzyk, w którym znajduje się troje dzieci (lub młodzieńców) - widoczne górne partie ciał. Wzdłuż obrzeża medalika napis częściowo zapisany syglami, zwykle rozdzielonymi kropkami umieszczonymi w połowie wysokości liter. Napis biegnie od dołu ku górze lewej strony, a po stronie prawej od góry, rozdziela go postać świętego. Napis: S[ANCTVS] • NICOLAUS D[E] •/BARI O[RA] • $\mathrm{P}[\mathrm{RO}] \cdot \mathrm{N}[\mathrm{OBIS}]$ (ryc. 3).

Miejsce znalezienia: w zasypisku grobu 115 , na poziomie $243,30 \mathrm{~m}$ n.p.m.

Dane o pochówku: pochówek w trumnie - podwójny(?), czaszka kobiety w wieku senilis, kręgosłup i pozostałe kości mężczyzny w wieku maturus. Szkielet usytuowany wzdłuż osi północny wschód - południowy zachód, wyprostowany, ręce zgięte, skrzyżowane z dłońmi na miednicy.

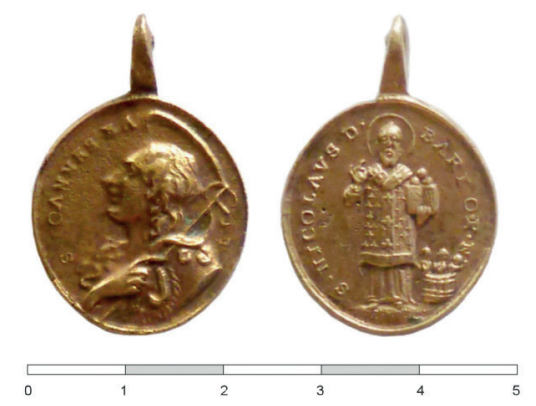

Ryc. 3. Medalik ze św. Janem na Av i św. Mikołajem na Rv, nr kat. 1 (fot. Z. Przepiórowski).

\section{Medalik lany dwustronny. Nr inwentarza polowego 39/2015.}

Opis: medalik o owalnym kształcie i wymiarach $1,8 \times 2 \mathrm{~cm}$, o grubości około $1 \mathrm{~mm}$. Posiada uszko o wysokości $6 \mathrm{~mm}$, uformowane szerszą stroną do płaszczyzny Av i Rv. W uszku znajduje się otwór do zawieszania o średnicy około $3 \mathrm{~mm}$. Medalik został odlany ze stopu metali kolorowych. Jest słabo czytelny, z płaskim reliefem konturowym.

Treść ikonograficzno-kultowa: na Av stojąca postać św. Benedykta. Dookoła głowy w przybliżeniu kolista aureola. W prawej, podniesionej ręce święty trzyma krzyż, w lewej, opuszczonej, prawdopodobnie księgę(?). Po lewej stronie 
postaci św. Benedykta znajduje się mitra biskupia oparta o pastorał. Po prawej stronie kruk. W górnej części medalika, wzdłuż otoku znajdują się litery, po stronie lewej: CRVX $\bullet \mathrm{S}$, po prawej $-\mathrm{P} \cdot \mathrm{BENEDICT}$, napis rozwinięty CRUX S.[ANCTI]/P[ATRIS] BENEDIC[TI].

$\mathrm{Na} \mathrm{Rv} w$ polu środkowym medalika krzyż św. Benedykta w kole z perełek. Pomiędzy ramionami krzyża litery C/S/P [B] czyli C[RUX]/S[ANCTI]/P[ATRIS] B[ENEDICTI]. Na krzyżu: ramię pionowe C[S] [...]; ramię poprzeczne S [...]D. Ramię pionowe C[RUX] S[ANCTA] S[IT] M[IHI] L[UX]. Ramię poziome N[ON] D[RACO] S[IT] M[IHI] D[UX]. Napis wzdłuż brzegu: IHS • $\mathrm{B} \cdot \mathrm{S} \bullet \mathrm{M} \bullet \mathrm{V} \bullet \mathrm{S} \bullet \mathrm{M} \bullet \mathrm{Q} \bullet \mathrm{L} \bullet \mathrm{I} \bullet \mathrm{V} \bullet \mathrm{B}$. Powinno być: IHS V R S N S M V S M Q L I V B - V[ADE] R[ETRO] S[ATANA] N[ON] M[IHI] S[VADE] V[ANA] S[UNT] M[ALA] Q[VE] L[IBAS] I[PSE] V[ENENA] B[IBAS]. Cztery pierwsze litery pomylone (ryc. 4).

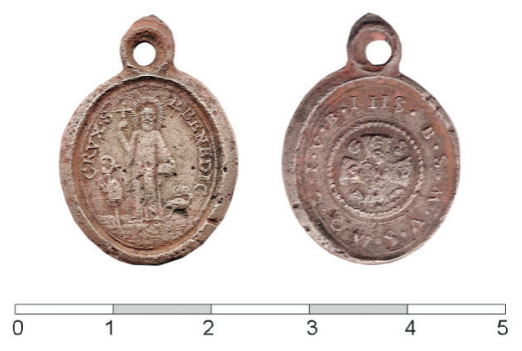

Ryc. 4. Medalik ze św. Benedyktem na Av i z krzyżem św. Benedykta na Rv, nr kat. 2 (fot. Z. Przepiórowski).

Miejsce znalezienia: w grobie 71, na wysokości miednicy, wraz ze szkiełkiem (nr kat. 12), na poziomie 243,36 m n.p.m.

Dane o pochówku: pochówek w trumnie. Szkielet usytuowany wzdłuż osi południowy zachód - północny wschód, wyprostowany, ręce wzdłuż tułowia, zgięte, dłonie złożone na miednicy - osobnik dorosły nieokreślonej płci.

\section{Medalik lany dwustronny. Nr inwentarza polowego 39/2015.}

Opis: drugi medalik znaleziony $\mathrm{w}$ grobie 71 , $\mathrm{z}$ fragmentem nici w uszku. Jest większy od pierwszego, posiada owalny kształt, wymiary 1,8 x 2,2 cm, grubość około $1 \mathrm{~mm}$ i wysokie uszko uformowane węższą stroną do płaszczyzny Av i Rv, ścienione ku górze, z otworem do zawieszania o średnicy około $1 \mathrm{~mm}$. Medalik odlano ze stopu metali kolorowych, w silnie wypukłym reliefie, z dobrze zarysowanymi przedstawieniami, ale o słabiej wypracowanych detalach. Na Rv przedstawienie dynamiczne, lekkie.

Treść ikonograficzno-kultowa: na Av postać św. Wojciecha(?) w pozycji stojącej, na wprost, w stroju biskupim. Święty w lewej ręce trzyma pastorał, 
a w prawej odciętą głowę(?). Napis po stronie lewej słabo czytelny, częściowo ucięty, zachowane w całości litery to: RTVS. Napis prawdopodobnie miał postać [S. ADALBE]RTVS (po łacinie imię Wojciecha - WOJTECHUS ADALBERTVS). Napis po stronie prawej ORA PR[O] N[OBIS].

$\mathrm{Na}$ Rv Anioł Stróż przedstawiony na wprost, w manierystycznej pozie, ze skrzydłami u ramion, w zwiewnej szacie o rozchylonych połach odsłaniających nogę z kolanem. Anioł prawą ręką trzyma dłoń dziecka i patrzy na nie z góry, lewa ręka podniesiona do góry. Dziecko w pozie kroczącej, z boku. Napis wzdłuż otoku, po lewej ANGELVS, po stronie prawej CVSTOS (ryc. 5).

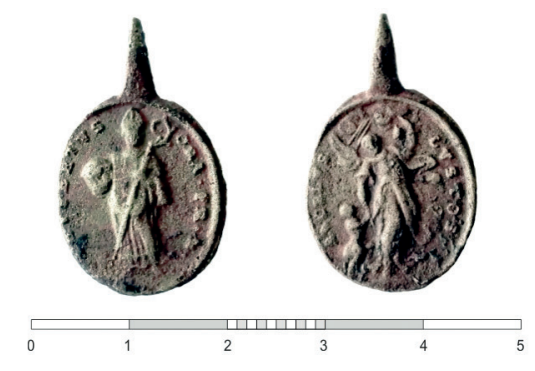

Ryc. 5. Medalik ze św. Wojciechem na Av i Aniołem Stróżem na Rv, nr kat. 3 (fot. Z. Przepiórowski).

Miejsce znalezienia: w grobie 71, na wysokości stóp zmarłego, na poziomie 243,25 m n.p.m.

Dane o pochówku: pochówek w trumnie. Szkielet usytuowany wzdłuż osi południowy zachód - północny wschód, wyprostowany, ręce wzdłuż tułowia, zgięte, dłonie złożone na miednicy - osobnik dorosły nieokreślonej płci.

\section{Medalik lany dwustronny. $\mathrm{Nr}$ inwentarza polowego 38/2015.}

Opis: medalik owalnego kształtu o wymiarach 2,8 x $3,5 \mathrm{~cm}$ i maksymalnej grubości około $3 \mathrm{~mm}$. Posiada uszko o wysokości $5 \mathrm{~mm}$, uformowane szerszą stroną do płaszczyzny Av i Rv, z otworem do zawieszania o średnicy około $3 \mathrm{~mm}$. Medalik ma także trzy, w przybliżeniu kuliste granule o średnicy około $2 \mathrm{~mm}$, po jednej na maksymalnych wygięciach dłuższych boków i jednej od spodu medalika, na osi z uszkiem. Zabytek odlano ze stopu metali kolorowych. Jest dobrze zachowany, starannie wykonany i obrobiony, z czytelnymi, plastycznymi reliefami.

Treść ikonograficzno-kultowa: na Av Matka Boska z Dzieciątkiem Jezus po prawej stronie. Matka Boska z Dzieciątkiem ukazana w popiersiu en trois quatre, bez korony, w welonie. Postacie Matki i Jezusa zwrócone do siebie twarzami, obejmują się rękami w czułym geście. Za głowami w przybliżeniu koliste aureole. Szaty lekko udrapowane, dekoracyjnie spływające. 
Na Rv popiersie en trois quatre św. Franciszka z Paoli. Święty przedstawiony w habicie, z kapturem na głowie i z kolistą aureolą za nią, w skrzyżowanych dłoniach trzyma krzyż oparty o lewe ramię. Rysy twarzy przedstawione schematyczne (ryc. 6).

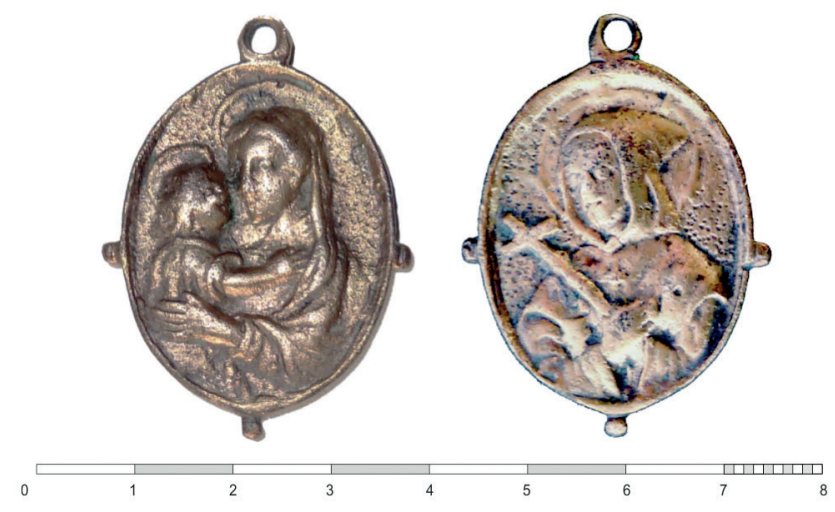

Ryc. 6. Medalik z Matką Boską z Dzieciątkiem na Av i św. Franciszkiem z Paoli na Rv, nr kat. 4 (fot. Z. Przepiórowski).

Miejsce znalezienia: w zasypisku grobu 31, w okolicach miednicy, na głębokości 243,47 m n.p.m.

Dane o pochówku: pochówek w trumnie. Szkielet usytuowany na osi południowy zachód - północny wschód, wyprostowany, ręce wzdłuż tułowia, lekko zgięte na wysokości dłoni złożonych na miednicy. Mężczyzna w wieku maturus - senilis.

\section{Medalik lany dwustronny. Nr inwentarza polowego $20 / 2015$.}

Opis: medalik owalnego kształtu o wymiarach $1,7 \times 2 \mathrm{~cm}$ i grubości około $1 \mathrm{~mm}, \mathrm{z}$ uszkiem o wysokości $7 \mathrm{~mm}$, ukształtowanym węższym bokiem do płaszczyzny Av i Rv, z otworem do zawieszania o średnicy 1,5 mm i z kółeczkiem z drutu o średnicy około $8 \mathrm{~mm}$ tkwiącym w otworze. Odlano go ze stopu metali kolorowych. Relief na Av słabo wyodrębniony, miejscami schematyczny, na Rv bardziej wypukły, lepiej czytelny.

Treść ikonograficzno-kultowa: na Av Matka Boska Częstochowska z Dzieciątkiem Jezus siedzącym na jej lewym przedramieniu. Oboje w koronach na głowach, za którymi znajdują się koliste aureole. Szaty gładkie. Jezus w ręce lewej trzyma zamkniętą księgę. Postacie Matki i Jezusa zeschematyzowane, twarze zaznaczone niewyraźnie, bez szczegółów.

$\mathrm{Na}$ Rv dwa Serca Gorejące z odchodzącymi od nich promieniami, umieszczone na obłokach. Wokół otoku napis - S S [SANCTISSIME] CORDA (ryc. 7).

Miejsce znalezienia: wykop 2, odcinek 1, poza grobami. 


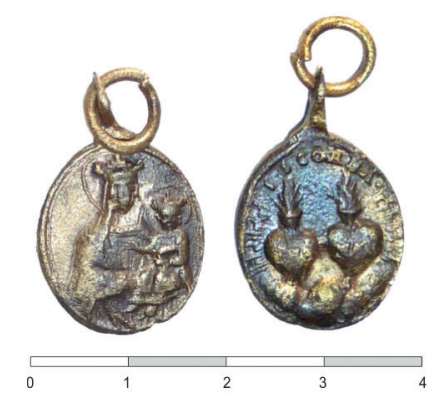

Ryc. 7. Medalik z Matką Boską z Dzieciątkiem Jezus na Av i z Sercami Gorejącymi na Rv, nr kat. 5 (fot. Z. Przepiórowski).

\section{Krzyżyk lany dwustronny. Nr inwentarza polowego 61/2015.}

Opis: krzyżyk z figurką Jezusa odlaną razem z nim, ramiona proste z obwódką (profilem) nieznacznie wznoszącą się nad płaszczyzną ramion. Wymiary krzyżyka - rozpiętość ramion $8 \mathrm{~cm}$, wysokość $2,5 \mathrm{~cm}$, z uszkiem do zawieszania o wysokości $8 \mathrm{~mm}$, uformowanym węższą stroną do frontu krzyża, oś uszka w płaszczyźnie krzyżyka. Zabytek odlano ze stopu metali kolorowych w głębokim reliefie, dobrze oddającym szczegóły.

Treść ikonograficzno-kultowa: na Av Chrystus Zbawiciel na krzyżu - przedstawienie frontalne $\mathrm{z}$ twarzą na wprost. Ręce i stopy przebite gwoździami. Biodra osłania perizonium związane na prawym boku, lekko zwisające i układające się w dwie poprzeczne fałdy. Lewa stopa za prawą, kolana delikatnie ugięte, wokół głowy promienisty nimb. Nad głową, lekko ukośnie, zamieszczono ozdobny titulus z literami INRI - IESVS NAZARENUS REX IVDAEORVM, pod stopami czaszka Adama (obcięta, podobnie jak prawa strona ramienia pionowego, poniżej skrzyżowania belek, czaszka zapewne spoczywała na skrzyżowanych piszczelach). Twarz Chrystusa bez śladów cierpienia o schematycznie zaznaczonych szczegółach.

Na Rv symbole Męki Pańskiej. Na belce pionowej, od góry: kielich - graal, poniżej kielicha trzy chleby, pośrodku krzyża serce, poniżej stopy, na samym dole skrzyżowane włócznia i trzcina, na której podano Chrystusowi gąbkę(?), pomiędzy nimi kolumna biczowania, a pod nią sakiewka, z wysypującymi się z niej srebrnikami(?). Na belce poziomej po stronie lewej przedstawiono, jak się wydaje kleszcze, a po prawej młotek, które zwykle umieszczano w ten sposób. Dłonie znalazły się po bokach serca. Od dłoni rozchodzą się promienie. Układ skrzyżowanych przedmiotów (usytuowanych wzdłuż linii kontynuujących się na belce poziomej jak i pionowej), może także sugerować, że są to: włócznia po prawej i fragment drzewca lub trzciny z gąbką po lewej. Skrzyżowanie włóczni $\mathrm{i}$ trzciny, tworzące $X$, może stanowić wymowny układ - pierwszą literę greckiej wersji imienia Chrystus, a kolumna może być odczytana jako zredukowane $\mathrm{P}$, 
czyli pełne imię Chrystusa. Kielich i serce symbolizują ponadto samego Chrystusa. Nie jest to zatem wyłączne przedstawienie narzędzi Męki Pańskiej, ich wymowa symboliczna jest znacznie głębsza. Kielich jest nawiązaniem do ofiary Chrystusa. Serce wiąże się z kolei z kultem Serca Jezusa, aczkolwiek w połączeniu z narzędziami Męki Pańskiej ma wymowę pasyjną. Wszystkie symbole i szczegóły dobrze odlane, czytelne (ryc. 8).

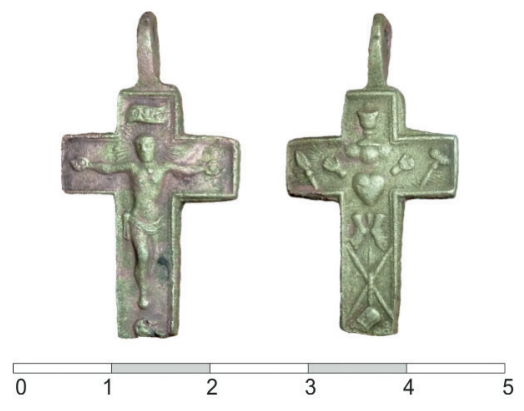

Ryc. 8. Krzyżyk z Ukrzyżowanym Chrystusem na Av i z symbolami Męki Pańskiej na Rv, nr kat. 6 (fot. Z. Przepiórowski).

Miejsce znalezienia: w okolicach grobu 160.

Dane o pochówku: pochówek w jamie, szkielet usytuowany wzdłuż osi południowy zachód - północny wschód, zachowane kończyny dolne. Szczątki w wieku infans I (0,5-1 rok) oraz kości, co najmniej dwóch osobników dorosłych.

\section{Medalik wybity z blachy, dwustronny. Nr inwentarza polowego 11/2015.}

Opis: medalik w kształcie ośmiokąta wydłużonego w pionie, o maksymalnych wymiarach $2 \times 2,7 \mathrm{~cm}$. Zachował się otwór do zawieszania o średnicy $2 \mathrm{~mm}$ i kółeczko z drutu tkwiące w otworze. Wykonano go z cienkiej blachy, prawdopodobnie mosiężnej o grubości około $0,5 \mathrm{~mm}$ przy użyciu mocno zużytej sztancy. Posiada ubytek wzdłuż dłuższej, prawej krawędzi, jest lekko zgięty i nieco spatynowany, przez co mało czytelny, zwłaszcza na Av.

Treść ikonograficzno-kultowa: na Av pełna postać świętego Benedykta. Wizerunek słabo czytelny, tak jak i napis [...] ENEDI[...], prawdopodobnie S[ANCTVS] BENEDIC[TVS].

$\mathrm{Na} \mathrm{Rv}$, pośrodku, znajduje się krzyż wyznaczony linią perełkową, nieregularny, chociaż powinien być równoramienny, o ramionach symetrycznie rozszerzających się ku końcowi (krzyż kawaleryjski). Na ramieniu pionowym litery CRUX SANCTI SIT MIHI LUX (krzyż święty niech będzie mi światłem), na ramieniu poziomym NON DRACO SIT MIHI DUX (diabeł (dosłownie smok) niech nie będzie mi przewodnikiem), przy czym drugie S z ciągu liter CSSML jest wspólne ze względu na swoje centrale położenie. W polach między ramio- 
nami C/S/P/B - CRUX SANCTA PATRIS BENEDICTI - krzyż św. oj. Benedykta. Napis wzdłuż brzegu IHS $\bullet \mathrm{V} \bullet \mathrm{R} \cdot \mathrm{S} \bullet \mathrm{N} \bullet \mathrm{S}$ M V S M Q L I V B czyli IHS VADE RETRO SATANO NON SVADE MIHI VANA SVNT MALA QVE LIBAS IPSE VENENA BIBAS, co oznacza: idź przecz szatanie, nie kuś mnie do próżności, złe jest to, co podsuwasz, sam pij swoją truciznę (ryc. 9).

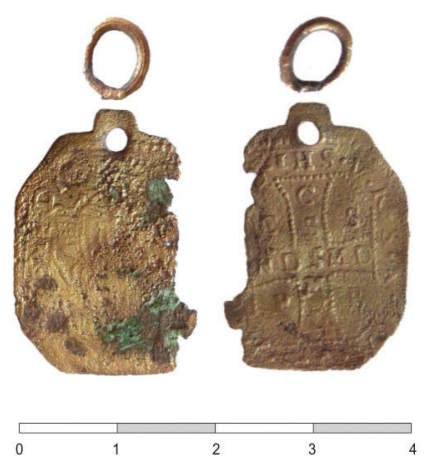

Ryc. 9. Medalik ze św. Benedyktem na Av i Krzyżem św. Benedykta na Rv, nr kat. 7 (fot. Z. Przepiórowski).

Miejsce znalezienia: w grobie 28, przy dłoniach złożonych na podołku wraz z paciorkami różańca (31 sztuk), na poziomie 243,71 m n.p.m.

Dane o pochówku: pochówek w trumnie o wymiarach (zachowanych): 170 x $40 \mathrm{~cm}$. Szkielet usytuowany na osi południowy zachód - północny wschód, wyprostowany, ręce lekko zgięte, dłonie na miednicy, należący do mężczyzny w wieku maturus, dodatkowo w trumnie kości kobiety w wieku maturus i dziecka w wieku infans I.

\section{Krzyżyk wybity z blachy, dwustronny. Nr inwentarza polowego 61/2015.}

Opis: zabytek w formie krzyża kawaleryjskiego. Wymiary maksymalne 2,3 x 2,6 cm. Jest lekko ułamany w części górnej, po lewej stronie, przy otworze do zawieszania o średnicy $3 \mathrm{~mm}$. Wykonano go z cienkiej blachy, prawdopodobnie mosiężnej, o grubości około 0,5 mm.

Treść ikonograficzno-kultowa: na Av znajduje się postać św. Benedykta w obszernej kukulli. W lewej ręce trzyma laskę - pastorał(?), w prawej księgę(?). Wokół głowy promienista aureola. Na belce poziomej krzyża, po stronie lewej litery od dołu do góry: CRVX - dewiza zakonu św. i dalej - S[ANCTI], następnie kolista wypukłość - kropka i kolejna litera P[ATRIS], po prawej stronie litery BENEDIC[TI] w pionie od góry ku dołowi.

$\mathrm{Na} \mathrm{Rv}$ pośrodku krzyża znajduje się ośmiokątny perełkowy otok, a w nim krzyż św. Benedykta. Na czterech polach wyznaczonych przez ramiona krzyża widnieją litery. Na belce poziomej litery od lewej do prawej - N D S M D 
- NON DRACO SIT MIHI DUX - diabeł (dosłownie smok) niech nie będzie mi przewodnikiem. Na belce pionowej litery od góry do dołu C S S M i L - CRUX SANCTI SIT MIHI LUX - krzyż święty niech będzie mi światłem. W narożach krzyża w czterech polach litery C/S/P/B (góra od lewej C/S i dół od lewej P/B) - CRUX SANCTA PATRIS BENEDICTI - krzyż św. oj. Benedykta. Nad belką pionową napis IHS i dalej zgodnie ze wskazówkami zegara [V.] R S N S M V [S M Q] L [I] V [B] - IHS VADE RETRO SATANO NON SVADE MIHI VANA SVNT MALA QVE LIBAS IPSE VENENA BIBAS. Brzegi ramion krzyża zdobione kolumnami drobnych równoległych kreseczek, odciśniętych tylko na Rv na ramieniu prawym i górnym (ryc. 10).

Miejsce znalezienia: w okolicach grobu 160.

Dane o pochówku: pochówek w jamie, szkielet usytuowany wzdłuż osi południowy zachód - północny wschód, zachowane kończyny dolne. Szczątki osobnika w wieku infans I (0,5-1 rok) oraz kości, co najmniej 2 osobników dorosłych.

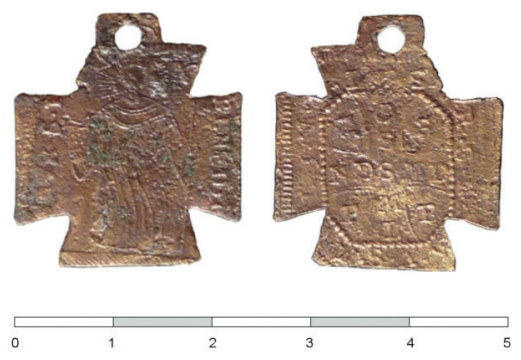

Ryc. 10. Krzyżyk ze św. Benedyktem na Av i krzyżem św. Benedykta na Rv, nr kat. 8 (fot. Z. Przepiórowski).

\section{Medalik dwustronnie szklany owalny. Nr inwentarza polowego 69/2015.}

Opis: egzemplarz o maksymalnych wymiarach 3,2 x 4,1 cm i grubości około $5 \mathrm{~mm}$. Składa się z dwóch szkiełek, porysowanych, zmatowiałych i lekko opalizujących, oprawionych w taśmę wykonaną ze stopu metali kolorowych. Taśma w przekroju profilowana, stanowi ramkę zachodzącą na szkła, zwłaszcza mocno na szkiełko Rv. Ramka po stronie zewnętrznej, krawędziowej w części środkowej jest zagięta do środka tworząc bruzdę, w której umieszczono drut. Okalał on cały medalik i łączył się prawdopodobnie z podwójnym uszkiem do zawieszania lub nawet te uszka tworzył. Ramka jest mocno skorodowana, zwłaszcza w okolicach uszek, a także lekko zniekształcona. Pomiędzy szkiełkami, wewnątrz obudowy z ramki, znajduje się mniejszy obrazek w przybliżeniu owalny, o wymiarach $1,8 \times 2,2 \mathrm{~cm}$. Zamocowano go pośrodku przestrzeni pomiędzy szybkami za pomocą cienkiego drucika lub drucików, zwiniętych w spiralki i spłaszczonych, okalających medalik wewnętrzny i utrzymujących 
go stabilnie pośrodku obudowy. W chwili obecnej, bez zdemontowania ramki i szkiełek zewnętrznych medalika, nie można ustalić z jakiego materiału wykonano medalik wewnętrzny i czy obrazki są papierowe, odbite, przyklejone do trwalszego podkładu, czy może jest to medalik malowany. Wyblakłe kolory obrazka wskazują raczej na to, że jest on papierowy, pierwotnie kolorowy. Medalik wewnętrzny zamocowano do góry nogami, ponieważ uszka do zawieszania znajdują się pod przedstawieniami we właściwym położeniu.

Treść ikonograficzno-kultowa: po jednej stronie medalika wewnętrznego odczytano wizerunek Maryi Panny z Dzieciątkiem. Matka Boska w koronie na głowie przedstawiona jest frontalnie, trzyma na kolanach małego Jezusa na wprost i obejmuje go rękami. Szczegóły obrazka są słabo czytelne.

$\mathrm{Na} \mathrm{Rv}$ postać trudna do zidentyfikowania, prawdopodobnie św. Józef z aureolą za głową, trzyma w ręce nieokreślony przedmiot (ryc. 11).

Miejsce znalezienia: w grobie 18, między kolanami zmarłego.

Dane o pochówku: pochówek w trumnie, wymiary: 186 x 42-46 cm, szkielet kompletny, wyprostowany, ręce lekko zgięte, dłonie razem złożone na miednicy. Usytuowany wzdłuż osi południowy zachód - północny wschód. Kobieta(?) w wieku adultus.

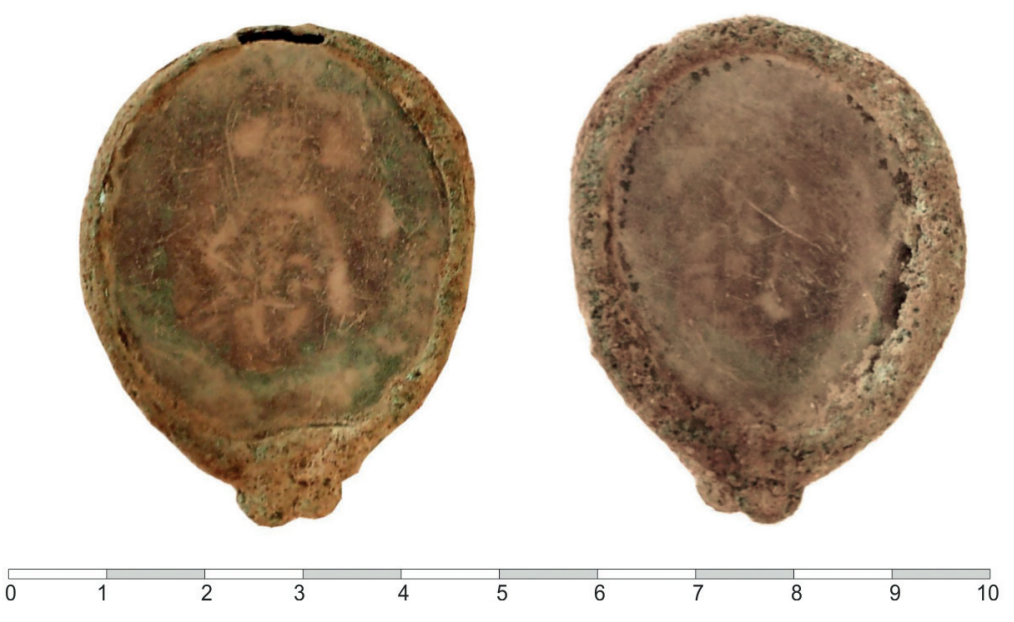

Ryc. 11. Medalik szklany z wizerunkiem Matki Boskiej z Dzieciątkiem na Av i św. Józefem z Dzieciątkiem na Rv, nr kat. 9 (fot. Z. Przepiórowski).

10. Medalik dwustronnie szklany, kolisty. Nr inwentarza polowego 57/2015.

Opis: egzemplarz o kolistym kształcie i o średnicy maksymalnej $3,5 \mathrm{~cm}$, w metalowej ramce, zdobionej żłobkami poprzecznymi po stronie zewnętrznej, krawędziowej. Na ramce, u góry, znajdowały się dwa zespolone kółeczka do zawieszania. Szybki matowe, pokryte kolorową, opalizującą patyną, zbite (pęk- 
nięte na pół, po obu stronach, na Rv ubytek szkła). Pomiędzy szybkami zachowały się strzępki papieru z nieczytelnym obrazkiem (ryc. 12).

Miejsce znalezienia: w grobie 149, na lewym udzie zmarłego.

Dane o pochówku: pochówek w trumnie, szkielet usytuowany wzdłuż osi południowy zachód - północny wschód, zachowane kości udowe i fragment miednicy. Osobnik dorosły.
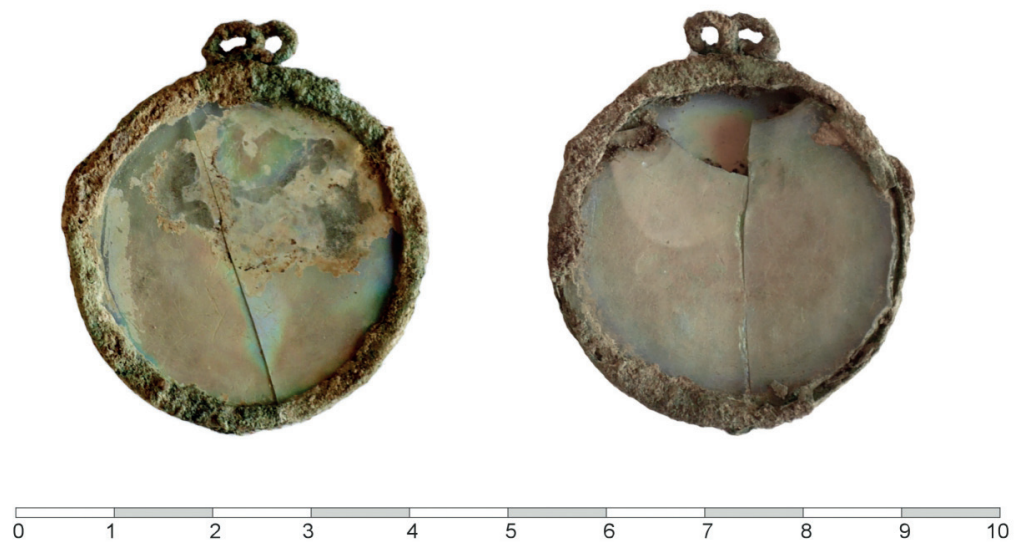

Ryc. 12. Medalik szklany, nr kat. 10 (fot. Z. Przepiórowski).

\section{Fragmenty medalika dwustronnie szklanego, kolistego. $\mathrm{Nr}$ inwentarza polowego 62/2015.}

Opis: zachowały się szkiełka o średnicy $2,9 \mathrm{~cm}$, a pomiędzy nimi zbutwiały kawałek papieru. Szkiełka zmatowiałe, na obrzeżach ślady łuszczenia formującego. Ramka z blachy ze stopu metali kolorowych mocno skorodowana uległa pokruszeniu. Pierwotnie była ona profilowana, z szeroką bruzdą podłużną pośrodku krawędzi zewnętrznej.

Treść ikonograficzno-kultowa: na strzępku papieru na jednej stronie (nie wiadomo Av czy $\operatorname{Rv}(?))$ głowa bliżej nierozpoznanego świętego, być może św. Franciszka z Asyżu (ryc. 13).

Miejsce znalezienia: w grobie 163, między prawym obojczykiem a pierwszym górnym żebrem.

Dane o pochówku: pochówek w jamie, szkielet usytuowany wzdłuż osi południowy zachód - północny wschód, $\mathrm{z}$ nogami podkurczonymi w kierunku wschodnim, prawa ręka wzdłuż tułowia $\mathrm{z}$ dłonią na udzie, lewa ręka zgięta $\mathrm{z}$ dłonią na miednicy. Szkielet kompletny, dodatkowo dwie luźne czaszki na prawym udzie. Szkielet kompletny - kobieta w wieku senilis. 


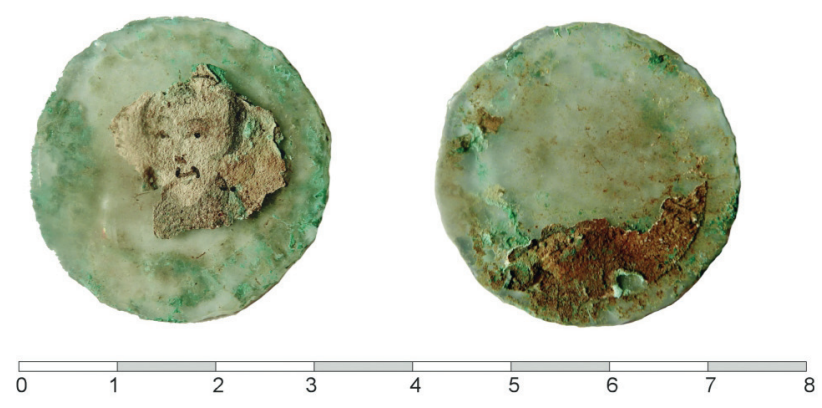

Ryc. 13. Medalik szklany z wizerunkiem św. Franciszka z Asyżu(?), nr kat. 11 (fot. Z. Przepiórowski).

\section{Fragment medalika szklanego, kolistego. $\mathrm{Nr}$ inwentarza polowego 39/2015.}

Opis: zachowało się pojedyncze szkiełko lekko owalnego kształtu o wymiarach 2 x 2,1 cm. Po obu jego stronach przyklejone były, prawdopodobne barwne, odbite na papierze obrazki. Przetrwały jedynie ich relikty. Na Av, z dużą dozą prawdopodobieństwa, można rozpoznać wizerunek Matki Boskiej z Dzieciątkiem Jezus na kolanach, przedstawionych frontalnie. Druga strona obrazka jest nieczytelna (ryc. 14).

Miejsce znalezienia: w grobie 71, na miednicy przy paliczkach lewej dłoni. W grobie tym znaleziono także dwa medaliki lane (nr kat. 2, 3).

Dane o pochówku: pochówek w trumnie, z której zachowało się wieko, ściany boczne i częściowo dno; wymiary: 166 x 32-38 cm. Szkielet kompletny, usytuowany na osi południowy zachód - północny wschód, wyprostowany, ręce wzdłuż tułowia, zgięte, dłonie złożone na miednicy. W zasypisku liczne luźne kości, w tym 6 czaszek. Pochówek główny - osobnik dorosły.

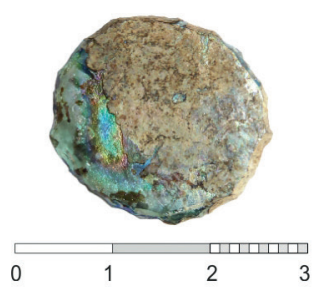

Ryc. 14. Medalik szklany z wizerunkiem Matki Boskiej z Dzieciątkiem Jezus na kolanach(?), nr kat. 12 (fot. Z. Przepiórowski). 


\section{Fragmenty medalika szklanego. Nr inwentarza polowego 52/2015.}

Opis: zarejestrowano 11 części potłuczonych dwóch szkiełek i 6 ułamków uszkodzonej ramki z taśmy. Nie zachowały się ślady papierowych obrazków.

Miejsce znalezienia: w grobie 136, w nogach, na udzie nad prawym kolanem, na poziomie $243,12 \mathrm{~m}$ n.p.m.

Dane o pochówku: pochówek w trumnie, szkielet usytuowany wzdłuż osi południowy zachód - północny wschód, wyprostowany, prawa ręka zgięta pod kątem prostym z dłonią na lewej ręce, lewa ręka zgięta $\mathrm{z}$ dłonią na miednicy. Brak czaszki. Czaszka leżała przy trumnie. Kobieta(?) w wieku maturus.

\section{Fragmenty medalika szklanego, kolistego. Nr inwentarza polowego 41/2015.}

Opis: zachowały się trzy fragmenty szkiełek, jednego całego o średnicy $3,5 \mathrm{~cm}$ i drugiego $\mathrm{w}$ dwóch kawałkach oraz trzy fragmenty bardzo silnie skorodowanej ramki. Na kolistych obrzeżach szkiełek ślady delikatnego łuszczenia formującego. Od strony wewnętrznej szkiełka zachowanego w całości relikty zbutwiałego, papierowego obrazka, nieczytelnego. Na obrzeżach szkiełek, od strony wewnętrznej, w przybliżeniu koliste ślady substancji łączącej - sklejającej szkiełka, o średnicy około 4-5 mm. Ramka ze stopu metali kolorowych, w przekroju lekko profilowana, z płytką, podłużną bruzdą na krawędzi zewnętrznej.

Miejsce znalezienia: wykop 2, odcinek 2, wkop 1 - ossuarium.

\section{Fragmenty medalika szklano-metalowego, prawdopodobnie prostokąt- nego. $\mathrm{Nr}$ inwentarza polowego $41 / 2015$.}

Opis: zachował się narożnik medalika, składającego się ze szkiełka i blaszki ze stopu metali kolorowych, połączonych ramką z tego samego materiału. Ramkę tworzy część blaszki zawiniętej i zachodzącej na część szklaną. Wewnątrz znajdował się kolorowy obrazek, do chwili znalezienia dotrwał w stanie reliktowym, nieczytelny.

Miejsce znalezienia: wykop 2, odcinek 2, wkop 1 - ossuarium.

\section{Różaniec - paciorki. Nr inwentarza polowego 11/2015.}

Opis: 29 paciorków i fragmentów paciorków kościanych barwy brązowej. Cztery z nich są większe od pozostałych, o średnicy około $8 \mathrm{~mm}$, lekko wydłużone przy wlocie i wylocie otworu do zawieszania na sznureczku lub nici. Pozostałe mają kształty beczułkowate i średnice około 5-6 mm. Otwory w koralikach o średnicach około $2 \mathrm{~mm}$ (ryc. 15).

Miejsce znalezienia: w grobie 28, przy dłoniach złożonych na podołku, przy ośmiokątnym medaliku św. Benedykta, na głębokości 243,71 m n.p.m.

Dane o pochówku: pochówek w trumnie, $\mathrm{z}$ której zachował się fragment deski z wieka oraz zarys na piasku, wymiary: 170 x $40 \mathrm{~cm}$. Szkielet usytuowany 
wzdłuż osi południowy zachód - północny wschód, wyprostowany, ręce lekko zgięte, dłonie na miednicy, należący do mężczyzny w wieku maturus, dodatkowo w trumnie kości kobiety w wieku maturus i dziecka w wieku infans I.

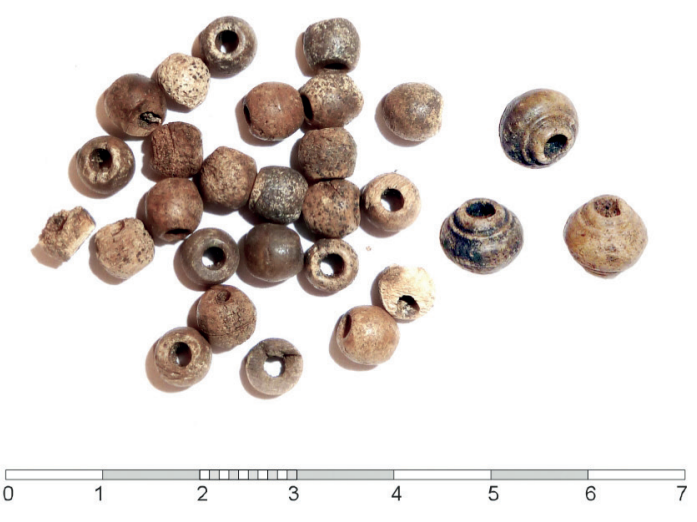

Ryc. 15. Paciorki różańca wykonane z kości, nr kat. 16 (fot. Z. Przepiórowski).

\section{Różaniec - paciorki. Nr inwentarza polowego 55/2015.}

Opis: 43 paciorki szklane (jeden w dwóch połówkach). Przy nich znaleziono fragment mocno skorodowanego i nieczytelnego medalika, owalnego kształtu o wymiarach 1,4 x 1,9 cm, pękniętego na pół. Paciorki są zróżnicowane pod względem kształtu, najczęściej beczułkowate, o minimalnej długości $9 \mathrm{~mm}$,

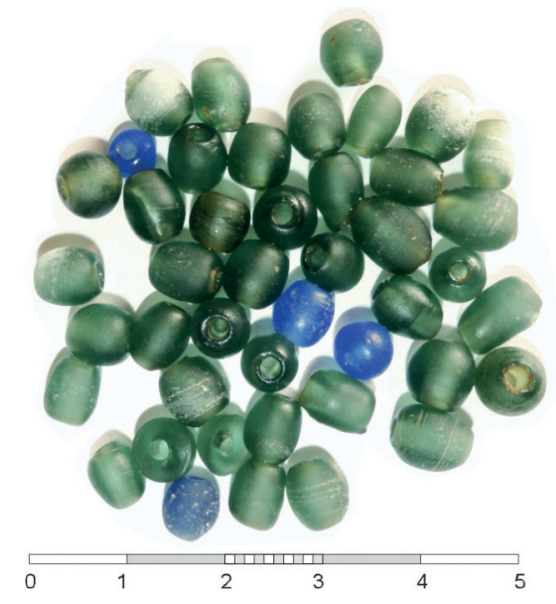

Ryc. 16. Paciorki różańca wykonane ze szkła, nr kat. 17 (fot. Z. Przepiórowski).

przy szerokości $8 \mathrm{~mm}$ i maksymalnej długości $11 \mathrm{~mm}$ i szerokości $9 \mathrm{~mm}$ oraz w przybliżeniu kuliste o średnicy $9 \mathrm{~mm}$. Jest także jeden egzemplarz wielokątny, najmniejszy, o średnicy $8 \mathrm{~mm}$ i wysokości $5 \mathrm{~mm}$. Posiadają otwory o śred- 
nicach od $2 \mathrm{~mm}$ do $4 \mathrm{~mm}$. 39 wykonano z lekko przezroczystego szkła koloru zielonego a cztery ze szkła barwy kobaltowej. Są one mocno starte, właściwy kolor widoczny jest jedynie po namoczeniu koralików. Wyróżniają się cztery egzemplarze koloru kobaltowego, trzy z nich są w przybliżeniu kuliste a jeden wielokątny (ryc. 16).

Miejsce znalezienia: w grobie 140, w okolicach miednicy, na poziomie 243,50 m. n.p.m.

Dane o pochówku: szkielet usytuowany wzdłuż osi południowy zachód - północny wschód, zniszczony, zachowane fragmenty lewej kończyny górnej, miednicy i prawej kończyny dolnej. Kobieta w wieku iuvenis/adultus.

\section{Różaniec. Nr inwentarza polowego 48/2015.}

Opis: 42 malutkie paciorki wykonane z gliny, barwy jasnobrązowej, jednakowego kształtu i wielkości. Paciorki to płaskie krążki o średnicy $4 \mathrm{~mm}$ i grubości około $2 \mathrm{~mm}$ (ryc. 17).

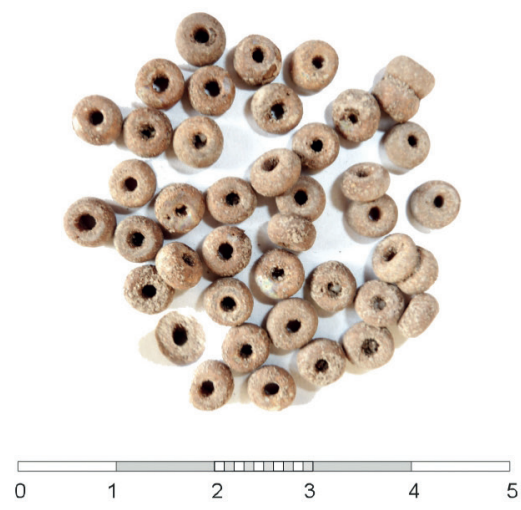

Ryc. 17. Paciorki różańca wykonane z gliny, nr kat. 18 (fot. Z. Przepiórowski).

Miejsce znalezienia: w grobie 114, w okolicy głowy dziecka wraz z zębem mlecznym, na poziomie 243,32 m n.p.m.

Dane o pochówku: pochówek w trumnie, szkielet usytuowany wzdłuż osi południowy zachód - północny wschód, wyprostowany, brak czaszki i kończyn górnych. Kości dwóch osobników: infans I (3-4 lata) i infans II (około 7 lat).

Termin dewocjonalia jest szeroki i mało precyzyjny, często utożsamiany z terminem medaliki. Wyraz „dewocjonalia” pochodzi od łacińskiego devocere oznaczającego poświęcić, przeznaczyć na ofiarę (Kołyszko 2013: 11). W literaturze ostatecznie nie rozstrzygnięto czym jest medalik pod względem formalnym i nie został on do końca zaklasyfikowany do konkretnej dziedziny badań. Z uwagi na podobieństwa formalne zawartych w nich treści medaliki 
można zaliczyć do poszerzonej definicji numizmatyki (Białobłocki 1992: 161). Funkcjonuje wiele definicji medalików. Medaliki - dewocjonalia to przedmioty przeznaczone do pobożnego użytku czy praktyk religijnych (obrazy, różańce, krzyże, figury, medaliki i in.) (Zalewski 1997: 54; Zemann i in. 2008: 372-374). Medalik, według słownika świeckiego, to mały medal z wizerunkiem Chrystusa, Matki Boskiej lub świętych, zwykle noszony przez katolików (Skorupka i in. 1968: 380). Zgodnie z inną, obszerną definicją medaliki to przedmioty niewielkich rozmiarów, metalowe blaszki o różnych kształtach, z wykonanymi w reliefie wyobrażeniami o charakterze religijnym, z reguły dwustronne, $\mathrm{z}$ otworkami do zawieszenia, o ikonograficznych przedstawieniach treści religijno-kultowych, przeznaczone do noszenia zwykle na szyi, a także małe przedstawienia na papierze i skórze, często chronione szkiełkami. Zawieszano je na łańcuszkach, tasiemkach, sznureczkach. Były wytwarzane z trwałych surowców, metali kolorowych: brązu, mosiądzu, tombaku lub złota, odpornych na korozję. Treściowo są one powiązane $\mathrm{z}$ miejscami słynącymi łaskami oraz wydarzeniami życia chrześcijańskiego i nosi się je również na wierzchu (Jędrzejczyk 1978: 271; Zalewski 1997: 54). Medaliki zwane są także drobnymi przedmiotami kultu osobistego, czy prywatnej dewocji oraz zawieszkami dewocyjnymi (Chudzińska 1998: 12). Służą do jawnego manifestowania religijności i przywiązania do pozaliturgicznych form dewocyjnych (Kriegseisen 2017: 43). Po błogosławieństwie lub poświęceniu są sakramentaliami i zalicza się je do przedmiotów kultu (Kołyszko 2013: 11)

W skład zbioru źródeł archeologicznych, zaliczonych do kategorii dewocjonaliów, pozyskanych z cmentarza przy kościele pw. św. Barbary w Częstochowie, wchodzi 14 eksponatów pojedynczych, które przetrwały w całości (9 sztuk, nr kat. 1-6, 8-10) i we fragmentach (nr kat. 11-15) oraz trzy niekompletnie zachowane różańce, składające się z 29 (nr kat. 16), 43 (nr kat. 17) i 42 paciorków (nr kat. 18). Najczęściej dewocjonalia występowały pojedynczo, tylko przy paciorkach dwóch różańców znajdowały się medaliki z blaszek, przy różańcu z paciorków kościanych (nr kat. 16) medalik bity (nr kat. 7) i przy paciorkach szklanych (nr kat. 17) medalik z blaszki (bardzo zniszczony i nieczytelny). W zasypisku grobu 71 znaleziono trzy zabytki, dwa medaliki lane i jeden szklany (z którego zachowało się tylko jedno szkiełko) (nr kat. 2, 3, 12). Nie można wykluczyć, że pierwotnie przedmioty te stanowiły „komplet” dla jednego zmarłego.

Zbiór dewocjonaliów jest zróżnicowany pod względem morfologicznym i stylistycznym, a przede wszystkim ikonograficznym. Nie ma dwóch powtarzających się egzemplarzy. Dewocjonalia reprezentują:

- medaliki metalowe, lane, dwustronne, o owalnych kształtach (nr kat. $1-5)$;

- medalik bity z blaszki, dwustronny, ośmiokątny (nr kat. 7), przy różańcu;

- krzyżyk metalowy, lany, dwustronny (nr kat. 6); 
- krzyżyk bity z cienkiej blaszki, dwustronny, w kształcie krzyża kawaleryjskiego (nr kat. 8);

- medaliki szklane, dwustronne, koliste i owalne (nr kat. 9-14);

- medalik szklano-metalowy, prostokątny(?) (nr kat. 15);

- fragmenty różańców z paciorków z gliny, kości i szkła (nr kat. 16-18), dwa różańce zawierały zawieszki;

- medalik z blaszki(?), pęknięty na pół i mocno skorodowany, nieczytelny (nr kat. 17), przy różańcu.

Wśród medalików metalowych są tradycyjne maryjne i z ikonografią hagiograficzną. Krzyżyk lany należy do typu IIa3, a bity do typu I (Kołyszko 2013: 23, 29, 39). Pozostałe egzemplarze, zwłaszcza medaliki szklane, nie doczekały się pełnego opracowania. Różańce uległy zerwaniu i zachowały sie fragmentarycznie, dlatego nie wnoszą informacji o ich budowie i nie pozwalają ustalić typu modlitwy, do odmawiania której miały być pomocne.

Medaliki i krzyżyk wykonane z metalu, odlane, dobrze przetrwały pobyt w ziemi. Podczas konserwacji usunięto z nich jedynie cienką warstwę korozyjną. Bardziej zniszczone były medalik i krzyżyk wybite $\mathrm{z}$ blachy, silniej skorodowane i mechanicznie uszkodzone, posiadały ubytki i lekkie deformacje. W najgorszym stanie dotrwały do naszych czasów medaliki szklane. Papierowe obrazki umieszczane między szkiełkami, pod wpływem wilgoci całkowicie zbutwiały lub rozłożyły się w znacznym stopniu. Tylko w przypadku dwóch egzemplarzy (nr kat. 9, 11), papier zachował się na tyle dobrze, że udało się odczytać wizerunki na obrazkach, a w przypadku trzeciego, bardzo źle zachowanego, wizerunku można się jedynie domyślać. W większości przypadków zniszczeniu uległy także szklane szybki i metalowe ramki. Szybki popękały, porysowały się i zmatowiały, ramki zaś pokruszyły się na kawałki, najczęściej bardzo drobne. Te, które przetrwały, były nieco zniekształcone. Różańce nie zachowały się w kompletach, gdyż rzadko można je znaleźć w całości. Zniszczeniu uległy nitki i sznureczki, na które nanizane były paciorki. Natomiast same koraliki dotrwały do czasu ich znalezienia w dobrym stanie, zwłaszcza kościane i gliniane. Paciorki szklane, mocno porysowane, stracily swoje pierwotne barwy, które można było ujrzeć jedynie po uprzednim ich zmoczeniu (ryc. 16).

Medaliki i krzyżyki metalowe (nr kat. 1-8) wytworzono w technikach odlewu lub bicia. Medaliki i krzyżyk lane, dwustronne (nr kat. 1-6), powstały ze stopu metali kolorowych wyłącznie w reliefie plastycznym. Surowca, z którego zostały odlane i wybite, nie określono, ale są to najprawdopodobniej brąz i mosiądz. Jedynie dwa medaliki (nr kat. 2, 3) wykonano niestarannie, prawdopodobnie w gorzej przygotowanych formach odlewniczych. Pozostałe zaś odlano $\mathrm{z}$ dużą starannością. Dwa z nich przypominają medale (nr kat. 1,4). Medaliki bite (nr kat. 7, 8) wytworzono z cienkich blaszek, na których dwustronną sztancą odciśnięto przedstawienia religijne, w reliefie płaskim, konturowym, z posta- 
ciami uwiecznionymi w sposób uproszczony. Medaliki i krzyżyki tego rodzaju były najczęściej niestarannie przycięte lub źle podłożone pod matrycę, co powodowało częściowe odcięcie otoku.

Medaliki szklane (nr kat. 9-14, ryc. 11-14) wykonywano z dwóch szklanych szybek, kolistych lub owalnych, oprawionych w metalowe ramki ze stopu metali kolorowych, pomiędzy którymi znajdował się obrazek odbity na papierze, zapewne pierwotnie barwny. Ramki robiono z taśm o przekrojach profilowanych (nr kat. 9, 10, 15), z dość głęboką bruzdą pośrodku strony zewnętrznej (nr kat. 9). W okazie nr kat. 9, w bruździe zachował się kawałek drutu, który prawdopodobnie okalał cały medalik i z niego uformowano uszka do zawieszania. Analogiczne wgłębienia - bruzdy zaobserwowano na innych, najczęściej pokruszonych, ramkach. Na tej podstawie można sądzić, że większość medalików szklanych posiadała drut wzmacniający całą ich konstrukcję. Z drutu zrobione były też uszka, na dwóch ramkach (nr kat. 9, 10) podwójne, zespolone. Ramkę okazu nr kat. 10 po zewnętrznej stronie ozdobiono skośnymi, poprzecznymi żłobkami. Na obrzeżach szkiełek znajdują się ślady łuszczenia formującego, nadającego szybkom właściwe kształty, a także koliste pozostałości nieokreślonej substancji kleistej, łączącej szkła. Pomiędzy szybkami umieszczano papierowe obrazki odbite, zapewne barwne, dwustronne. Kolory obrazków wyblakły. Tylko na dwóch medalikach szklanych (nr kat. 9, 10) udało się zidentyfikować przedstawienia na obrazkach, w przypadku trzeciego istnieją wątpliwości co do określenia wizerunku. Nieco inny jest medalik szklany znaleziony w grobie 18 , między kolanami zmarłego (nr kat. 9). Jest to największy medalik tej odmiany. Wewnątrz, pomiędzy szkiełkami, w centralnej części ramki znajduje się obrazek mniejszy od szkiełek obudowy. Pośrodku utrzymują mały obrazek cieniutkie druciki, spiralki, ściśle okalające go od zewnątrz. Nie wiemy, czy jest to obrazek odbity dwustronnie, na twardszym, nieokreślonym materiale, czy może na nim namalowany. $\mathrm{W}$ celu rozstrzygnięcia tego problemu, medalik należałoby rozłożyć na części, co grozi jego uszkodzeniem. Ponadto obrazek w środku zamocowano do góry nogami, ponieważ uszka do zawieszania szklanej obudowy znajdują się pod obrazkami z przedstawieniami we właściwym położeniu. W ossuarium, w wykopie 2, znaleziono również fragmenty medalika szklano-metalowego (nr kat. 15). Zachował się jedynie jego narożnik. Medalik ten reprezentuje pojedynczy okaz tego typu, prawdopodobnie prostokątnego kształtu. Część metalową również wykonano ze stopu metali kolorowych. Obrazek papierowy nie zachował się.

Pozostałościami różańców, zwanych też sznurami modlitewnymi lub koronkami, są koraliki i koraliczki wykonane z gliny, kości zwierzęcych i szkła (nr kat. 16-18). Nawlekano je na sznurki, na końcu których często zawieszano krzyżyki lub medaliki, a niekiedy kilka zawieszek. Paciorki różnią się między sobą pod względem wielkości, barw i kształtów. Znalezione na cmentarzu „za miastem” 
reprezentowały kształty: kuliste, wrzecionowate, beczułkowate, wielokątne i krążkowate. Najwięcej odnotowano koralików szklanych - 43 sztuki (nr kat. 17, ryc. 16), a wśród nich najliczniejsze są okazy o kształcie beczułkowatym, mniej liczne w przybliżeniu kuliste. W tym komplecie jest także jeden paciorek wielokątny, najmniejszy. Wśród paciorków szklanych 39 wykonano z lekko przezroczystego szkła barwy zielonej, a cztery ze szkła barwy kobaltowej. Wyróżniają się paciorki koloru kobaltowego, trzy są w przybliżeniu kuliste i jeden wielokątny (ryc. 16). 29 paciorków i fragmentów paciorków zrobiono z kości. Większe od pozostałych są cztery z nich, lekko wydłużone przy wlocie i wylocie otworu do zawieszania, pozostałe mają kształty beczułkowate (ryc. 15). 42 jednakowe, malutkie paciorki w kształcie płaskich krążków wytworzono z gliny. Znaleziono je w grobie dziecka (ryc. 17). Koraliczki różańców z kości zwierzęcej i gliny, były wykonane bardzo starannie, choć materiał, z jakiego je zrobiono, może świadczyć o ubóstwie ich właścicieli. Stan zachowania nie pozwala ma określenie konstrukcji różańców. Nie wiemy, jaka była ich pierwotna ilość w sznurze i czy były rozdzielane na segmenty.

Z uwagi na duży stopień zniszczenia cmentarza i zaburzenie stratygrafii obiektów w wyniku wielokrotnego ich naruszania, tylko w 9 grobach udało się uchwycić i zaobserwować położenie dewocjonaliów w konkretnych miejscach na szczątkach zmarłych (gr. 18 - nr kat. 9 (tabl. I); gr. 28 - nr kat. 7, 16 (tabl. II); gr. 31 - nr kat. 4 (tabl. I); gr. 71 - nr kat. 2, 3, 12 (tabl. I); gr. 114 - nr kat. 18 (tabl. II); gr. 136 - nr kat. 13 (tabl. II); gr. 140 - nr kat. 17 (tabl. III); gr. 149 - nr kat. 10 (tabl. I); gr. 163 - nr kat. 11 (tabl. II)). Pozostałe eksponaty pochodzą z zasypisk jam grobowych (gr. 115 - nr kat. 1), z okolic grobów (gr. 160 - nr kat. 6, 8), z terenu poza jamą grobową - z obiektu zniszczonego (wykop 2 - nr kat. 5) oraz z wykopu 2 - ossuarium (nr kat. 14, 15). Dewocjonalia, które znalazły się poza jamami grobowymi w wyniku przekopania starych grobów w celu założenia nowych, a także z powodu zniszczeń inwestorskich w czasach współczesnych, straciły swój pierwotny kontekst. Wśród części tzw. znalezisk luźnych, można się dopatrywać i takich, które zgodnie z panującymi wówczas zwyczajami, wrzucano do jam grobowych lub, którymi przystrajano trumny oraz mogiły (Chudzińska 1998: 11).

Najczęściej dewocjonalia znajdowano na wysokości splecionych dłoni złożonych na podołku (w okolicach miednicy). Tak było w czterech przypadkach: w grobie 28 (medalik z blaszki leżał z paciorkami różańca przy dłoniach), w grobie 140 (paciorki różańca zalegały w okolicy miednicy z fragmentami mocno skorodowanego medalika), w grobie 71 (szkiełko medalika i jeden medalik metalowy z wizerunkiem św. Benedykta znaleziono w okolicach miednicy, przy paliczkach lewej dłoni) i w grobie 31 (medalik znajdował się w okolicach miednicy). Medaliki lub różaniec wkładano do ręki, rzadziej kładziono na piersiach lub rozkładano wzdłuż boku zmarłego. Często różańcami obwiązywano 
dłonie, aby się nie przemieściły w czasie opuszczania zwłok do grobu. Zwyczaj oplatania rąk zmarłych wprowadzono w XVI w., a regułą stał się w następnym stuleciu (Chudzińska 2008: 356). Inne miejsca znalezienia dewocjonaliów to: okolice głów, obojczyków, ud, nad kolanami i na wysokości stóp. W grobie 114 paciorki różańca leżały obok czaszki dziecka, a w grobie 163 medalik szklany przy obojczyku. W trzech grobach medaliki szklane znaleziono przy udach, tak, jak w przypadku grobu 136 (w nogach nad prawym kolanem), w grobie 18 (między kolanami) i w grobie 149 (na lewym udzie). Medaliki szklane zapewne trzymane były w rękach wyciągniętych wzdłuż ciała. Tylko w jednym grobie (163) odkryto szklany medalik przy prawym obojczyku i w jednym przypadku, w grobie 71, drugi medalik lany z wizerunkami św. Wojciecha i Anioła Stróża znajdował się na wysokości stóp.

Tematyka przedstawień na medalikach i krzyżykach jest bardzo różnorodna. Interesujące są także zestawienia wizerunków na obu stronach, np. św. Jan i św. Mikołaj, św. Wojciech i Anioł Stróż, Matka Boska i św. Franciszek z Paoli. Autorka artykułu ma wątpliwości, czy dobrze ustaliła pierwszeństwa stron medalików, np. czy św. Jan powinien być na Av, czy też św. Mikołaj. Ponieważ kult św. Jana należy do najstarszych, on, według autorki, powinien być zamieszczony na Av. Nasuwa się także inne pytanie, czy były to połączenia przypadkowe, czy wynikały z jakiejś konkretnej przyczyny czy reguły. Z kaplicą św. Barbary, a także z Jasną Górą próbowano wiązać legendę o pobycie św. Wojciecha w Częstochowie, który w klasztorze jasnogórskim miał wyśpiewać Bogurodzice (Zbudniewek 2002: 207). Można się zastanawiać, czy ta legenda miała jakiś wpływ na przedstawienie właśnie tego świętego na częstochowskim medaliku.

Na medalikach widnieją postacie i symbole: Chrystusa, Matki Boskiej z Dzieciątkiem Jezus, św. Józefa, św. Benedykta, św. Jana Chrzciciela, św. Mikołaja, św. Franciszka z Paoli, św. Franciszka z Asyżu, św. Wojciecha, Anioła Stróża, są także krzyże św. Benedykta, Serca Gorejące i symbole Męki Pańskiej. Wizerunek Matki Boskiej pojawił się na dwóch medalikach lanych (nr kat. 4, 5) i na dwóch obrazkach w medalikach szklanych (nr kat. 9, 12), św. Benedykt na trzech medalikach - jednym lanym (nr kat. 2) i na dwóch wybitych na blaszce (nr kat. 7, 8). Chrystus przedstawiony jako dziecię występuje cztery razy - na rękach Matki na dwóch medalikach lanych (nr kat. 4, 5) i na dwóch obrazkach medalików szklanych - na rękach i kolanach Matki Boskiej (nr kat. 9, 12), a także, jako Zbawiciel na jednym krzyżyku lanym (nr kat. 6). Pozostałe przedstawienia świętych i symboli się nie powtarzały. Zgodnie z zaleceniami soboru trydenckiego, medaliki popularyzowały głównie wizerunki Najświętszej Maryi Panny, własnych patronów, a także świętych wywodzących się z ich wspólnot, stąd święci o rodowodach jezuickich i franciszkańskich (Chudzińska 1998: 24). 
Największą popularnością cieszyły się medaliki z wizerunkami Chrystusa i Najświętszej Marii Panny. Matkę Boską przedstawiano z Synem, Chrystusa najczęściej jako Dzieciątko na rękach Matki lub Świętych. Są także wizerunki Chrystusa Zbawiciela na krzyżu (Chudzińska 1998: 171, tabl. XXIV).

Wszystkie medaliki z wizerunkiem Matki Boskiej poświęcone były macierzyństwu Maryi. Większość odmian dotyczących tajemnicy Bożego macierzyństwa Maryi powstała na Jasnej Górze (Zemann i in. 2008: 373-374). Na medalikach lanych i na obrazkach umieszczonych między szybkami szklanymi znajdują się różne wizerunki Matki Boskiej. Na jednym widnieje Matka Boska Częstochowska z Dzieciątkiem Jezus, obydwoje w koronach i w aureolach za głowami (nr kat. 5, ryc. 7), na innym Matka Boska z Dzieciątkiem Jezus po prawej stronie $-\mathrm{w}$ welonie, postacie bez koron (nr kat. 4, ryc. 6). Na obrazkach wizerunek Matki Boskiej z dzieciątkiem jest bardzo słabo czytelny. Matka Boska Częstochowska oddana poprawnie na medalikach występuje zawsze w krótkiej półpostaci. Dziecię Jezus pokazane jest w całej postaci, matka trzyma je siedzące na lewej ręce, a prawą ma położoną na piersi. Dziecię z reguły prawą ręką wskazuje na swoją matkę, a w lewej trzyma zamkniętą książkę (Jędrzejczyk 1978: 275). W świecie katolickim i w Polsce kult maryjny przybrał formę wyjątkową. Matkę Boską otaczano niezwykłym nabożeństwem. Do Maryi modlono się w każdej intencji, polecano jej chorych i konających. Jej opieka nie kończyła się wraz z życiem doczesnym, wyjednywała ona łaski zbawienia dla dusz odrzuconych i czyśćcowych (Chudzińska 1998: 27; 2008: 349-350). Z polskich wizerunków Matki Boskiej należy wynieść przede wszystkim Madonnę Jasnogórską z Częstochowy, znaną z medalików bitych i malowanych na różnych materiałach oraz relikwiarzyków i szkaplerzy (Chudzińska 2008: 352). Sława cudów Matki Boskiej Częstochowskiej i zwyczaj pielgrzymowania na Jasną Górę znajduje potwierdzenie źródłowe już w początkach XV w. (Kunczyńska-Iracka 1978: 14). W XVI w. ruch pątniczy do Częstochowy przybrał na sile, jednak największy rozkwit nastąpił dopiero $\mathrm{w}$ dwu następnych stuleciach (Kunczyńska-Iracka 1978: 15). Pełne upowszechnienie kultu Matki Boskiej Częstochowskiej, znacznie przerastające swym zasięgiem jakąkolwiek z innych miejscowości pątniczych w Polsce, nastąpiło po roku 1655, po zwycięstwie Polaków nad wojskami szwedzkiego króla Karola Augusta. Sława cudownego wizerunku rozeszła się szeroko. Jasnogórski wizerunek Matki Boskiej jako pierwszy obraz na ziemiach polskich został ukoronowany w 1717 r. (Rewoliński 1887: 12; Jędrzejczyk 1978: 274).

$\mathrm{Na}$ jednym papierowym obrazku medalika szklanego rozpoznano postać św. Józefa(?) (nr kat. 9, ryc. 11). Obrazek jest jednak bardzo słabo czytelny. Św. Józef cieszył się czcią wiernych, jako oblubieniec Maryi, opiekun małego Jezusa oraz patron rodziny (Lexikon 1960: szp. 1129-1130; Attwater, John 1997: 225-226; Chudzińska 1998: 27). 
Wizerunek św. Benedykta znalazł się na dwóch medalikach, lanym (nr kat. 2, ryc. 4) i wybitym (nr kat. 7, ryc. 9) oraz na krzyżyku wybitym stemplem (nr kat. 8, ryc. 10). Jest przedstawiony tradycyjnie, jako postać stojąca w kukulli, która w prawej ręce trzyma krzyż, w lewej prawdopodobnie księgę(?). Przez całe wieki wkładano medaliki tego świętego do grobów. Wiąże się to z czcią, jaką otaczano św. Benedykta, modląc się do niego, jako do patrona dobrej i szczęśliwej śmierci, niepozwalającej odejść bez pojednania się z Bogiem (Attwater, John 1997: 68-69). Św. Benedykt dokonywał cudów i miał dar proroctw. Artyści przedstawiali go jako brodatego starca o surowym spojrzeniu, w obszernym płaszczu mniszym, z krzyżem w ręku, błogosławiącego, trzymającego wskazujący palec na wargach. Medalik św. Benedykta stał się bardzo popularny w XVII i XVIII w. (Hiżycki 2005: 7-11), a egzemplarze z postacią tego świętego były najbardziej rozpowszechnionym typem zawieszek dewocyjnych w całej katolickiej Europie (Chudzińska 1998: 31; Gadacz i in. 2001: 13). Powszechnie utrzymywała się wiara w ich cudowną moc. Zapewniały ochronę przed szatanem i złymi siłami oraz różnymi nieszczęściami, dlatego, mimo, że większość była mało efektowna, nosili je chętnie także przedstawiciele warstw wyższych (Chudzińska 2008: 354). Magiczną rolę pełnił napis - odstraszał złe moce (Attwater, John 1997: 68-69). Nie wiadomo, kiedy dokładnie medaliki św. Benedykta zostały wybite po raz pierwszy. Wywodzą się z Niemiec, gdzie były już znane w XV w., a w wieku XVII szeroko się rozpowszechniły (Gadacz i in. 2001: 13). Krzyżyki św. Benedykta były wybijane lokalnie, z nieprecyzyjną obróbką, niestaranie obrobionym stemplem w wielu odmianach, różniących się kształtem (owalne, okrągłe, w kształcie ośmiobocznej tarczy lub krzyża kawaleryjskiego). Kształt zawieszek nie był obojętny. Medaliki ośmio- lub siedmiokątne przypominały tarczę - symbol Bożej opieki (Forstner 1990: 13, 471).

Postać św. Jana Chrzciciela została przedstawiona na jednym z najstaranniej wykonanych medalików lanych, z najładniejszym reliefem plastycznym (nr kat. 1, ryc. 3). Zawiera wizerunek młodzieńca. Kult Jana Chrzciciela należy do najdawniejszych. Jest on patronem kowali i misjonarzy, tkaczy, krawców, kuśnierzy, rymarzy, oberżystów, chorych na padaczkę, niezamężnych matek i skazanych na śmierć. Jest także orędownikiem w czasie gradobicia. Głównym symbolem - atrybutem św. Jana jest baranek. Uwieczniany jest najczęściej jako mężczyzna odziany w skórę zwierzęcą i udzielający chrztu, z krzyżem w dłoni. Często również symbolem świętego jest ścięta głowa złożona na tacy (Marecki, Rotter 2009: 304-305). Św. Jana jako młodzieńca zaczęto przedstawiać od czasów odrodzenia, ale w takiej postaci na medalikach występuje rzadko.

Po drugiej stronie medalika lanego ze św. Janem rozpoznano św. Mikołaja w stroju biskupim (nr kat. 1, ryc. 3). Mikołaj był biskupem Miry - stolicy jego rodzinnej prowincji Licji w Azji Mniejszej. Znany był z wielkiej wrażliwości na ludzką biedę i nieszczęścia. Przedstawiano go w stroju biskupim z pastorałem. 
Jego najważniejszymi atrybutami są: chleb, troje dzieci w cebrzyku, kotwica i okręt, księga, trzy złote kule (lub trzy jabłka) na księdze i worek z podarunkami. Medaliki z postacią św. Mikołaja były bardzo często używane w XVII i XVIII w. (Janicka-Krzywda 1993: 72; Sobczak 2000: 141-142: Słabek 2002: 209-211).

$\mathrm{Na}$ jednym medaliku rozczytano postać św. Franciszka z Paoli (nr kat. 4, ryc. 6). Prowadził on życie pustelnicze i zorganizował wspólnotę eremitów w Asyżu. Przedstawia się go w habicie minimitów, a jego atrybuty to: baranek, kij pielgrzymi, płaszcz, promienisty napis Charitas, osioł przy kuźni, różaniec, statek, trupia czaszka, zakładnik, kaptur (Marecki, Rotter 2009: 219).

Św. Franciszek z Asyżu widnieje, jak się wydaje, na bardzo słabo czytelnym obrazku papierowym między szkiełkami medalika (nr kat. 11, ryc. 13). Urodzony w Asyżu był ascetą, mistykiem, stygmatykiem, opiekunem chorych i ubogich. Przedstawiany był w habicie franciszkańskim lub w szacie pokutnej. Jego atrybutami były: baranek, czaszka, krzyż, księga, kula ziemska, ryba, ptaki i inne (Zalewski 1997: 77; Marecki, Rotter 2009: 219, 225).

$\mathrm{Na}$ kolejnym medaliku lanym widnieje św. Wojciech w pozycji stojącej, w stroju biskupim z pastorałem (nr kat. 3, ryc. 5). Urodził się w Libicach w Czechach, zginął śmiercią męczeńską w Prusach. Po studiach w Rzymie był przez pewien czas biskupem Pragi. Podczas bierzmowania przyjął imię Albertus. Znany i czczony jest pod dwoma imionami. W Polsce, jako Wojciech, główny patron Polski, a w świecie chrześcijańskim, jako Adalbert. Relikwie św. Wojciecha spoczywają w Gnieźnie. Jego atrybutami są anioł, ampułki, obraz Matki Bożej, orzeł, naczynie na wodę, wiosło, włócznia, głowa trzymana w ręku, itd. (Zalewski 1997: 17, 281; Marecki, Rotter 2009: 621).

Po drugiej stronie medalika lanego przedstawiającego św. Wojciecha, widnieje postać Anioła Stróża w zwiewnej szacie, ze skrzydłami u ramion, trzymająca za rękę dziecko (nr kat. 3, ryc. 5). Pierwsze wizerunki postaci anielskich pochodzą ze wschodu, z Bizancjum (Timbal 2012: 34, 261). O aniołach mówił św. Tomasz z Akwinu i inni XIII-wieczni teologowie (Timbal 2012: 36-37). Anioły są posłańcami Boga, narzędziami Opatrzności, wspierają człowieka w osiąganiu ostatecznego celu, są u jego boku jednocześnie dysponentem darów Bożych zarówno w porządku naturalnym jak i nadprzyrodzonym (Zalewski 1997: 17; Longosz 2002: 1-205; Danielou 2006: 20). Równolegle do aniołów kościołów istnieją też anioły poszczególnych wiernych, zwani Aniołami Stróżami, którzy pomagają zrozumieć wolę Bożą. Anioły Stróże nazywane są także dozorcami, opiekunami, czyli mającymi pieczę przełożonych (Danielou 2006: 20). W polskiej literaturze teologicznej nie można znaleźć wielu publikacji na temat aniołów. Te, które są, mają na ogół charakter pobożnościowy, a prace ściśle teologiczne należą do rzadkości (Danielou 2006: 5). W Polsce kult Anioła Stróża opiekuna, zwłaszcza dzieci, jest powszechnie znany i silny od wieków. 
Medaliki z postaciami aniołów znajdują się także w katalogu Teofila Rewolińskiego i zostały one zakwalifikowane przez autora jako medaliki „dawne” (Rewoliński 1887: 14).

Serca Gorejące, jako symbol religijny, przedstawiono na medaliku lanym (nr kat. 5, ryc. 7). Wiążą się one ze Świętymi Sercami i kultem Serc Jezusa i Maryi. Serce oznacza miłość, jako centrum iluminacji i szczęścia, stąd też występuje uwieńczone płomieniami, krzyżem, kwieciem lilii, koroną (Cirlot 2001: 366).

Na medalikach i krzyżykach, poza przestawieniami postaci, znajdują się legendy - napisy umieszczane najczęściej otokowo, biegnące koliście lub owalnie, blisko krawędzi medalików. Występują jedynie po łacinie. Wykonano je majuskułą z szeryfami. W wypadku medalików św. Benedykta są one rozmieszczone także poziomo i pionowo, w obrębie krzyża w formie liter - skrótów, symboli. W polach między ramionami znajdują się litery rozdzielone kropkami. Są to pierwsze litery słów układających się w tekst. Najczęściej medaliki były „podpisane” imieniem świętego i anioła, przedstawionego na medaliku, np. JOANNES, BENEDICTI, NICOLAVS, ANGELVS, albo były uzupełnieniem symboli CORDA, IHS, wreszcie INRI - IESUS NAZARENUS REX IUDAEORUM. Na medalikach św. Benedykta znajdowały się pełne teksty, np. VADE RETRO SATANA NUMGNAM SUADE MIHI VANA SUNT MALA RUAE LIBAS IPSE VENONA BIBAS - idź precz szatanie, nie kuś mnie do próżności, złe jest to, co podsuwasz, sam pij swoją truciznę.

Na przedstawionych medalikach znajdowały się wyobrażenia świętych powszechnie znanych w świecie chrześcijańskim, do których ich posiadacze mieli specjalne nabożeństwo. Matka Boska, Chrystus, święci, byli orędownikami w konkretnych sprawach, co często decydowało o wyborze patrona. W XVII i XVIII w. chętnie zaopatrywano się w medaliki z wyobrażeniami patronów dobrej śmierci. Najczęściej uciekano się do Matki Boskiej i św. Benedykta. Na wielu przedstawiano także św. Franciszka z Asyżu (Chudzińska 2008: 354). Medaliki religijne są bardzo ciekawym źródłem do poznania ikonografii świętych i błogosławionych, a także obrzędowości Kościoła katolickiego i mogą być ważne i bardzo pomocne w datowaniu warstw archeologicznych (Kriegseisen 2017: 46).

Różańce wykonane z paciorków nawleczonych na sznurki, służyły do modlitwy różańcowej, którą wprowadził św. Dominik w XIII w. (Gadacz i in. 2001: 502-503; Kitowicz 2003: 27-28), choć istnieje także pogląd, iż prawdopodobnie około wieku XII z użyciem różańca odmawiano modlitwę maryjną Ave Maria, którą z czasem połączono z modlitwą Pater Noster (Kołyszko 2013: 153).

Pierwsze, większe kolekcje medalików i krzyżyków pochodzą z XIX w. Najliczniejszy jest zbiór T. Rewolińskiego. Katalog tego zbioru ukazał się w 1887 r. i nadal pozostaje podstawową, najpełniejszą i najważniejszą pozycją biblio- 
graficzną. Niewiele jest starszych publikacji dotyczących tego typu zabytków (Kriegseisen 2017: 43). Drugim ważnym opracowaniem jest monografia obejmująca medaliki religijne z Matką Boską Częstochowską (Jędrzejczyk 1978).

Medaliki, które powstały przed wiekiem XIX są zabytkami o trudnej do określenia chronologii. Nie mają sygnatur, ani dat rocznych. Wiedza o ich producentach jest także znikoma, nie znamy nazwisk ani warsztatów produkcyjnych. Do naszych czasów nie dotrwały tablice nagrobne, epitafia, ani księgi zgonów, które byłyby pomocne w ustalaniu wytwórców i warsztatów. Przy określaniu chronologii dewocjonaliów nie sprawdza się także archeologiczna analiza stratygraficzna. Zniszczeniu uległy pierwotne układy warstw, a groby leżące na tym samym poziomie trudno uznać za sobie współczesne (Chudzińska 1998: 47-48). Cmentarze przekopywano wielokrotne, już w czasie ich użytkowania - przy zakładaniu wciąż nowych pochówków oraz później, kiedy przenoszono groby do wspólnych jam - ossuariów. Z powodu „kurczenia się” powierzchni cmentarzy przy kościołach, używanych nieprzerwanie od wieków, w ten sposób szykowano miejsca na nowe pochówki.

Także analiza stylistyczna niewiele wnosi do określania chronologii medalików. Widniejący na nich święci są bardzo popularni w świecie chrześcijańskim, a kanony obowiązujące przy ich przedstawianiu generalnie przez wieki nie podlegały zmianom, albo poddawały się im z wielkim trudem. Wizerunki często się powtarzają lub nawiązują do znacznie starszych niż one same. Ponadto medaliki, stanowiące często pamiątki rodzinne, otoczone czcią i emocjonalnym przywiązaniem, były przechowywane przez pokolenia (Chudzińska 1998: 47-48).

Przy ustalaniu chronologii dewocjonaliów, a zwłaszcza medalików i krzyżyków z cmentarza przy kościele św. Barbary, przyjęto szerokie ramy czasowe odpowiadające okresowi użytkowania cmentarza i kościoła. Tak, więc można je datować bardzo ogólnie, na wiek XVII, XVIII i prawdopodobnie początek wieku XIX, bo do tego okresu używano cmentarza „za miastem”. Żaden z zaprezentowanych medalików nie jest, jak się wydaje, starszy. Noszenie medalików i zawieszek dewocyjnych upowszechniło się dopiero w wieku XVII (Chudzińska 1998: 48). Medaliki św. Benedykta stały się bardzo popularne w XVII w. (Hiżycki 2005: 7-11), tak jak i medaliki z przedstawieniami Matki Boskiej po koronacji obrazu w 1717 r. (Kunczyńska-Iracka 1978: 14). Medalik z wizerunkiem Matki Boskiej z Dzieciątkiem, bez korony, w welonie, mógł być wykonany nieco wcześniej, przed koronacją obrazu. Inne okazy nie wnoszą istotnych informacji o okresie ich powstania.

Wizerunki spotykane na zawieszkach odpowiadają ogólnie przyjętym i powielanym wzorom. B. Chudzińska w swojej pracy poświeconej medalikom z cmentarza w Maniowach stawia ciekawe pytania: skąd brały się pomysły na przedstawienia wizerunków świętych na medalikach; w jakim stopniu twórcy czerpali wzory z kościołów, w których bywali, czy napotykali na trudności 
z ich oddaniem w pracowniach rytowników i malarzy, czy też realizowali swoje własne wizje? Kwestię tę mogą rozstrzygnąć jedynie wnikliwe studia nad tym tematem (Chudzińska 1998: 28).

Jak już wcześniej wspomniano, niewiele wiemy o warsztatach produkujących dewocjonalia, zwłaszcza siedemnasto- i osiemnastowiecznych. Niesygnowane dewocjonalia stwarzają trudności w rozpoznaniu ich wytwórcy - wydawcy, wykonawcy i okresu jego wytworzenia - wydania. Przedmioty te mogły być produkowane w pracowniach anonimowych rzemieślników, świeckich i zakonnych (Chudzińska 1998: 15). Każdy region ma własne, lokalne kulty. Częstochowa była i jest centrum kultu Matki Boskiej Częstochowskiej, stąd medaliki z jej wizerunkiem były tu najliczniejsze i najbardziej charakterystyczne. Można sądzić, że większoość tych medalików a można i zaryzykować tezę, że wszystkie, powstały prawdopodobnie w Częstochowie, a zwłaszcza w Częstochówce, w okolicach klasztoru jasnogórskiego. W XVII w. istniał tu dobrze zorganizowany przemysł, zajmujący się produkcją dewocjonaliów (Orynżyna 1976: 115; Kunczyńska-Iracka 1978: 70, 80, 90). Wytwórczość medalików biegła dwoma nurtami - dla przeciętnego i wymagającego odbiorcy. Choć brak systematycznych studiów nad tym problemem, można posłużyć się analogiami do działalności drzeworytników i obraźników. Rzeźbieniem klocków zajmowali się przede wszystkim „samorodni artyści” wywodzący się z chłopów, pospólstwa miejskiego, a nawet drobnej szlachty. W przypadku obraźników częstochowskich dla biedniejszych odbiorców produkcją zajmowali się mniej biegli rzemieślnicy lub przyuczeni do zawodu amatorzy, ewentualnie rezygnowano z wykorzystania tajników sztuki kosztem zwiększenia ilości wyrobów i dostosowywano się do gustów klientów. Wykonanie form do odlewów czy matryc do bicia zawieszek metalowych było z pewnością trudniejsze i wymagało odpowiednich narzędzi, ale nie na tyle, aby nie mogli tego robić obdarzeni właśnie „samorodnym talentem" (Kunczyńska-Iracka 1978: 111). Dewocjonalia siedemnasto- i osiemnastowieczne są głównie wytworem rąk rzemieślników, których umiejętności nie stały na wysokim poziomie. Przedstawiane postacie miały najczęściej zeschematyzowane rysy, pozbawione emocjonalnego wyrazu. Jednak wiele wyrobów z tego okresu cechuje wrażliwość i indywidualizm, których brak zawieszkom dziewiętnastowiecznym, produkowanym maszynowo. Wówczas tanie medaliki i krzyżyki bite były niekiedy w milionowych emisjach (Kuczyńska-Iracka 1978: 111).

Medaliki i krzyżyki pozyskane z wykopalisk na cmentarzu przy kościele pw. św. Barbary, były zróżnicowane nie tylko pod względem tematyki przedstawień, ale także wykonania. Reprezentowały zarówno okazy o wysokich walorach rzemieślniczych, jak i egzemplarze wykonane w nieco gorszej, prymitywnej technice. Do grupy pierwszej zaliczają się: medalik lany z postacią Matki Boskiej z Dzieciątkiem Jezus i z wizerunkiem św. Franciszka z Paoli (ryc. 6) oraz okaz 
z wizerunkami św. Jana Chrzciciela i św. Mikołaja (ryc. 3). Grupę drugą reprezentuje medalik z Matką Boską z dzieciątkiem Jezus i z Sercami Gorejącymi (ryc. 7) oraz eksponat ze św. Wojciechem i Aniołem Stróżem (ryc. 5). Dość starannie odlano i wykończono także krzyżyk z postacią Zbawiciela i symbolami Męki Pańskiej (ryc. 8).

Oceny tego typu nie są wolne od subiektywizmu, mimo to, pokuszę się o stwierdzenie, że wymienione wyżej medaliki pochodzą z dobrze wykonanych form i są starannie obrobione po odlaniu. Twórcy matryc $\mathrm{z}$ wizerunkami św. Jana i Matki Boskiej w welonie, wykazali się wysokim poziomem artystycznym. Na uwagę zasługują staranne wykonanie i ogólna, nieco inna konwencja i kompozycja obrazu, odbiegająca od powszechnie stosowanych kanonów.

W 2012 r. przeprowadzono archeologiczne badania wykopaliskowe na cmentarzu staromiejskim przy kościele pw. św. Zygmunta w Częstochowie, znajdującym się w obrębie dawnych murów miejskich. Pozyskane z tego cmentarza dewocjonalia znajdują się $\mathrm{w}$ trakcie opracowywania. Niewiele $\mathrm{z}$ nich, jak już wiadomo ze wstępnego sprawozdania, stanowi analogie do tych, które znaleziono na cmentarzu przy kościele pw. św. Barbary. Analogiczne są jedynie pospolite medaliki św. Benedykta - wybijane z blachy w kształcie krzyżyków i ośmiokątnych zawieszek (np. św. Barbara - z okolic gr. 160 i gr. 28; św. Zygmunt - gr. 47 i gr. 61), krzyżyki lane (np. św. Barbara - z okolic gr. 160; św. Zygmunt - gr. 61) oraz medaliki z wizerunkiem Matki Boskiej Częstochowskiej i z Sercami Gorejącymi (np. św. Barbara - poza obiektem, wykop 2; św. Zygmunt - gr. 40A), (Marek i in. 2014: 203-204). Mam nadzieję, że po opracowaniu wszystkich medalików z cmentarza przy kościele św. Zygmunta znajdzie się więcej analogii do eksponatów z cmentarza leżącego niedaleko, ale już poza murami Częstochowy, zwanego „za miastem”.

\author{
Iwona Młodkowska-Przepiórowska \\ Usługi Archeologiczno-Konserwatorskie \\ ul. Letniskowa 59, Tylin \\ 42-233 Mykanów \\ e-mail: tylin13@op.pl
}




\section{Bibliografia}

Attwater D., John C.R., (1997), Dykcjonarz świętych, Ossolineum, Wrocław.

Białobłocki K. (1992), Zespół medalików z wykopalisk archeologicznych w Lubiniu pod Kościanem, „Slavia Antiqua”, t. XXXIII, s. 161-184.

Borowska-Antoniewicz J. (2002), Urbanistyka i rozwój przestrzenny, [w:] F. Kiryk (red.), Częstochowa. Dzieje miasta i Klasztoru Jasnogórskiego, t. 1, Okres staropolski, Urząd Miasta Częstochowy, Częstochowa, s. 447-477.

Chudzińska B. (1998), Dewocjonalia z nowożytnego cmentarzyska we wsi Maniowy na Podhalu, Oficyna Cracovia, Kraków.

Chudzińska B. (2008), Nowożytne dewocjonalia z badań archeologicznych z terenu Polski poludniowo-wschodniej $i$ wschodniej Słowacji. Różnice i podobieństwa, „Матеріали і Дослідження з Археології Ррикарпаття і Волині”, випуск 12, Львів (Інститут українознавства ім. І. Крип'якевича НАН Укаїни), s. 346-359 .

Cirlot J.E. (2001), Słownik symboli, Wydawnictwo Znak, Kraków.

Danielou J. (2006), Aniołowie i ich misja, Fronda PL sp. z o.o., Apostolicum, Warszawa-Ząbki.

Forstner D. (1990), Świat symboliki chrześcjańskiej, Instytut Wydawniczy Pax, Warszawa.

Gadacz T. i in. (red.) (2001), Encyklopedia Religii, t. 2, Wydawnictwo Naukowe PWN, Warszawa.

Hiżycki Sz. (2005), Medalik Św. Benedykta, Wydawnictwo Benedyktynów Tyniec, Kraków.

Janicka-Krzywda U. (1993), Patron - atrybut - symbol, Wydawnictwo Pallottinum, Poznań.

Jędrzejczyk M.L. (1978), Medaliki Matki Boskiej Częstochowskiej (ze zbioru ks. S. Librowskiego), „Archiwa, Biblioteki i Muzea kościelne”, t. 36, Lublin, s. 268-348.

Kitowicz J. (2003), Opis obyczajów i zwyczajów za panowania Augusta III, Krakowska Spółka Wydawnicza, Warszawa.

Kołyszko M. (2013), Dewocjonalia z końca XVI-XVIII wieku pochodzace z badań archeologicznych na terenie Polski (stan zachowania, identyfikacja, zagadnienia konserwatorskie), Wydawnictwo Naukowe Uniwersytetu Mikołaja Kopernika, Toruń.

Kriegseisen J. (2017), Medaliki religijne XVI-XVIII wieku - forma, treść, funkcja, [w:] K. Kluczwajd (red.), Klejnoty w stużbie sacrum i dewocji. Biżuteria w Polsce, Rzemiosło artystyczne i wzornictwo w Polsce, t. XVI, Toruński Oddział Stowarzyszenia Historyków Sztuki, Toruń, s. 43-47.

Kunczyńska-Iracka A. (1978), Malarstwo ludowe kręgu częstochowskiego, Zakład Narodowy im. Ossolińskich, Wrocław.

Lexikon... (1960), Lexikon für Theologie und Kirche, t. 5, Verlag Herder, Freiburg.

Longosz S. (2002), Opiekuńcza funkcja Aniołów w nauce Ojców Kościoła (zarys problemu), [w:] H. Oleschko (red.), Księga o aniołach, Wydawnictwo WAM, Kraków, s. 150-205. 
Marecki J., Rotter L. (2009), Jak czytać wizerunki świętych. Leksykon atrybutów i symboli hagiograficznych, Towarzystwo Autorów i Wydawców Prac Naukowych Universitas, Kraków.

Marek R., Wojcieszak M., Wojcieszak J. (2014), Wyniki badań archeologicznych na terenie parafii pw. Św. Zygmunta w Częstochowie, województwo śląkie, [w:] G. Glanc-Zagaja (red.), Badania archeologiczne na Górnym Ślasku i ziemiach pogranicznych $w$ latach 2011-2012, Śląskie Centrum Dziedzictwa Kulturowego, Katowice, s. 195-205.

Młodkowska-Przepiórowska I. (2015), Sprawozdanie z badań archeologicznych ratowniczych - wykopaliskowych przeprowadzonych w maju/czerwcu 2015 roku przy zbiegu ulic Nadrzecznej i Jaskrowskiej w Częstochowie, Częstochowa, maszynopis dostępny w archiwum Wojewódzkiego Konserwatora Zabytków w Katowicach - Delegatura w Częstochowie.

Orynżyna J. (1976), Dewocjonalia częstochowskie, „Polska Sztuka Ludowa - Konteksty", t. 30(2), s. 115-120.

Rajman J. (2002), Rozwój miasta do połowy XVII wieku, [w:] F. Kiryk (red.), Częstochowa. Dzieje miasta i Klasztoru Jasnogórskiego, t. 1, Okres staropolski, Urząd Miasta Częstochowy, Częstochowa, s. 165-202.

Rewoliński T. (1887), Medale religijne odnoszace się do Kościoła katolickiego we wszystkich krajach dawnej Polski w zbiorze Dr med. T. Rewolińskiego, Nakładem Autora, Kraków.

Skorupka S. i in. (red.) (1968), Mały słownik języka polskiego, Państwowe Wydawnictwo Naukowe, Warszawa.

Słabek P. (2002), Św. Mikołaj, Wydawnictwo M, Kraków.

Sobczak J. (2000), Święci i ich symbole, Wydawnictwo Święty Wojciech, Poznań.

Szklarz-Habrowski A. (2018), Topografia szpitala - przytułku działajacego przy kaplicy/kościele św. Barbary w Starej Częstochowie, na przełomie XVIII i XIX w., „Kwartalnik Historii Kultury Materialnej”, r. LXVI, nr 1, s. 59-73.

Szymański S. (1965), Administracyjne i przestrzenne przeobrażenia Częstochowy w latach 1815-1830, „Ziemia Częstochowska”, t. 5, s. 5-48.

Timbal N. (2012), Aniołowie, posłańcy światła, Wydawnictwo Księży Marianów Promic, Warszawa.

Zalewski S. (red.) (1997), ABC Chrześcijanina. Mały słownik, Wydawnictwo Księży Werbistów Verbinum, Warszawa.

Zbudniewek J. (2002), Parafia Św. Zygmunta, [w:] F. Kiryk (red.), Częstochowa. Dzieje miasta i Klasztoru Jasnogórskiego, t. 1, Okres staropolski, Urząd Miasta Częstochowy, Częstochowa, s. 205-237.

Zemann E. i in. (red.) (2008), Encyklopedia katolicka, t. 12, Katolicki Uniwersytet Lubelski, Lublin. 


\section{SUMMARY}

\section{A COMPLEX OF DEVOTIONAL ITEMS AT THE CEMETERY NEAR THE ST. BARBARA CHURCH IN THE OLD TOWN OF CZESTOCHOWA}

In 2015, during the reconstruction of Nadrzeczna Street and Bohaterów Getta Square, in the area of the intersection with Jaskrowska Street, it was made the discovery of human bone remains. As a result of the rescue investigations undertaken, an area of approximately 550 square meters was tested. They were discovered among others relics of foundations, made of broken limestone and remains of the cemetery. The historical research showed that these foundations were relics of the St. Barbara church, around which there was a churchyard cemetery called "the cemetery outside the city" in the sources. At the remains they were found rosary beads, medallions, crosses, single glass beads, iron buttons, bronze and bone coins, hooks, buckles, pieces of cloth and textile and haberdashery ornaments. Particularly noteworthy is the collection of religious items. The collection of devotional items includes 14 exhibits. It is a diverse collection in terms of morphological and stylistic, and above all iconographic. Metal medallions and crosses were made from non-ferrous metals in casting or minting techniques. The minted medallions were made from thin badges. Glass medallions were made from two glass panes, bound in a metal frame, between which there was an image reflected on the paper. The remains of rosaries are beads, differing in terms of size, colors and shapes. Only in 9 graves it was managed to set the position of devotional items on the remains of the deceased. Most often, devotions were found at the height of clasped hands folded in the lap. Other places where devotional items are found are: around the head, around the clavicle, around the thigh - above the knees and at the feet level. The subject of images on medallions and crosses is diverse. The sets of images on the obverses and other sides are also interesting. On one picture of a glass medallion it was identified the figure of Saint Josef. The figure of St. Benedict was on two medallions. The figure of St. John the Baptist was presented on one of the most carefully made cast medallions. On its other side it was recognized St. Nicholas. On the next medal, the figure of St. Francis of Paola was identified. St. Francis of Assisi appears on a very poorly legible paper picture. On the medal lion we can see St. Wojciech. On its other side there is a figure of the Guardian Angel holding the child by a hand. Burning Hearts are presented on a cast medal, on the other side of the medal with St. Wojciech. The most popular were the medallions with images of Christ and the Virgin Mary. The Polish images of the 
Mother of God should be taken in account, first of all, Madonna of Jasna Góra from Częstochowa. On the medallions and crosses except the characters, there are legends - inscriptions, only in Latin, made them by majuskuła with sheriffs. Most often, the medallions were ,signed” by the name of the saint. In the seventeenth and eighteenth centuries, they were gladly supplied with medallions with the patrons of good death. In determining the chronology of devotional items from the church cemetery at the church of Saint Barbara, a wide chronological framework was adopted, corresponding to the period of use of the cemetery and the church, from the 17th century to probably the beginning of the 19th century. Częstochowa was the center of worship of Our Lady of Jasna Góra. It can be assumed that most of the medallions with images of the Virgin of Częstochowa, and perhaps even all of them, were probably created in Częstochowa. 

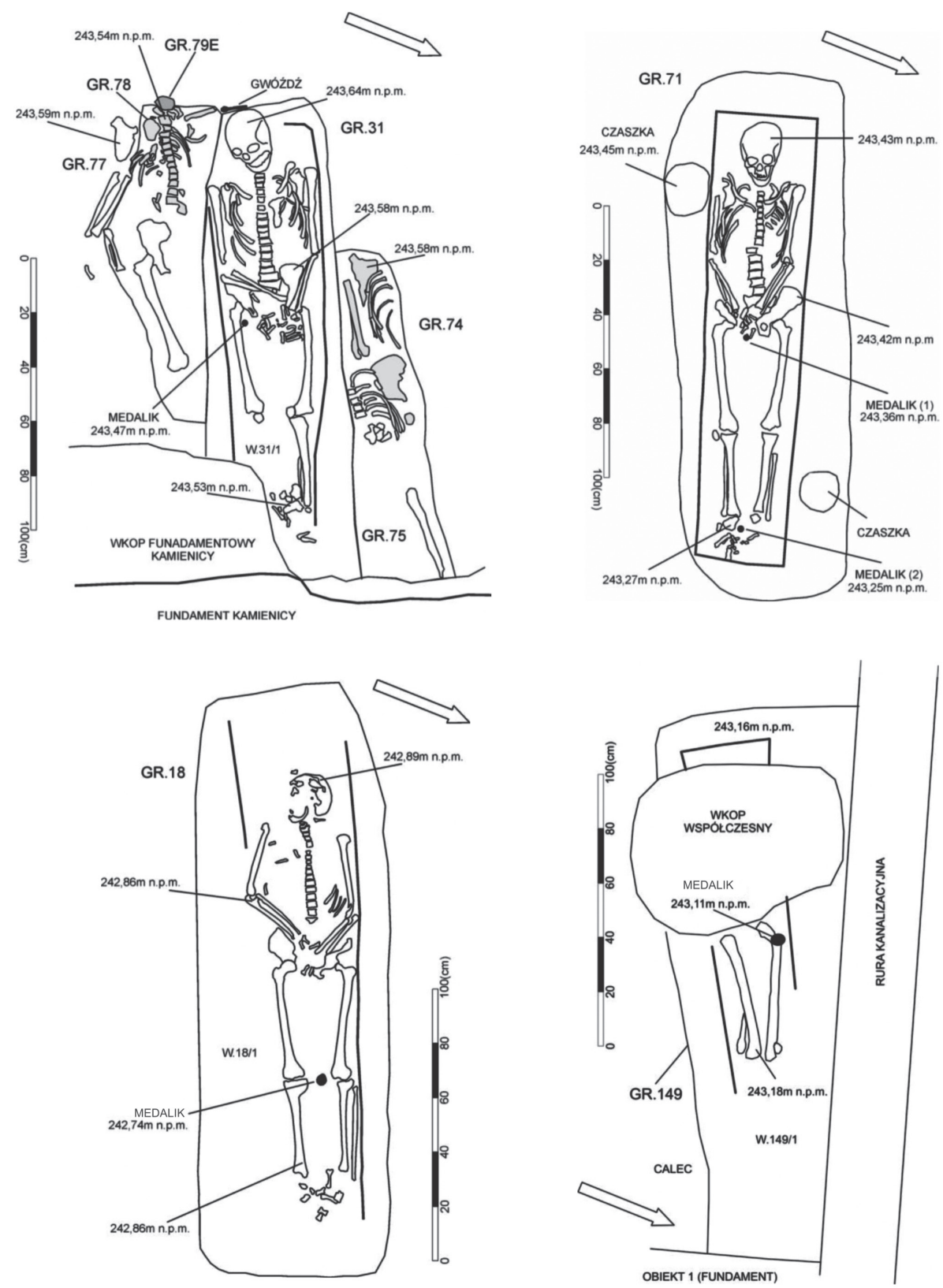

Tabl. I. Częstochowa Stare Miasto, stan. 49 (AZP 86-48/1), ul. Nadrzeczna/Jaskrowska. Plany grobów z dewocjonaliami: 18, 31, 71, 149 (rys. Z. Małek). 

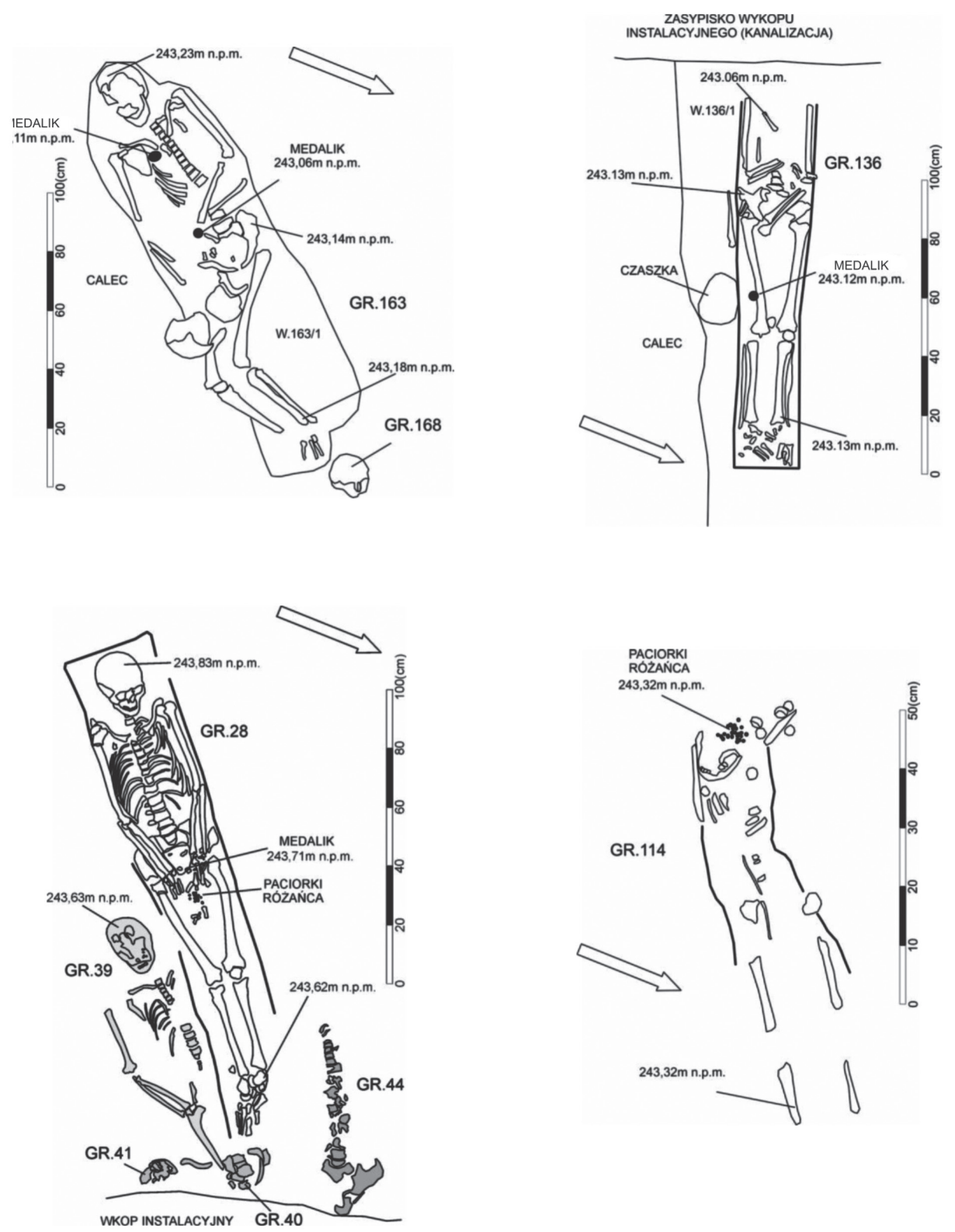

Tabl. II. Częstochowa Stare Miasto, stan. 49 (AZP 86-48/1), ul. Nadrzeczna/Jaskrowska. Plany grobów z dewocjonaliami: 28, 114, 136, 163 (rys. Z. Małek). 


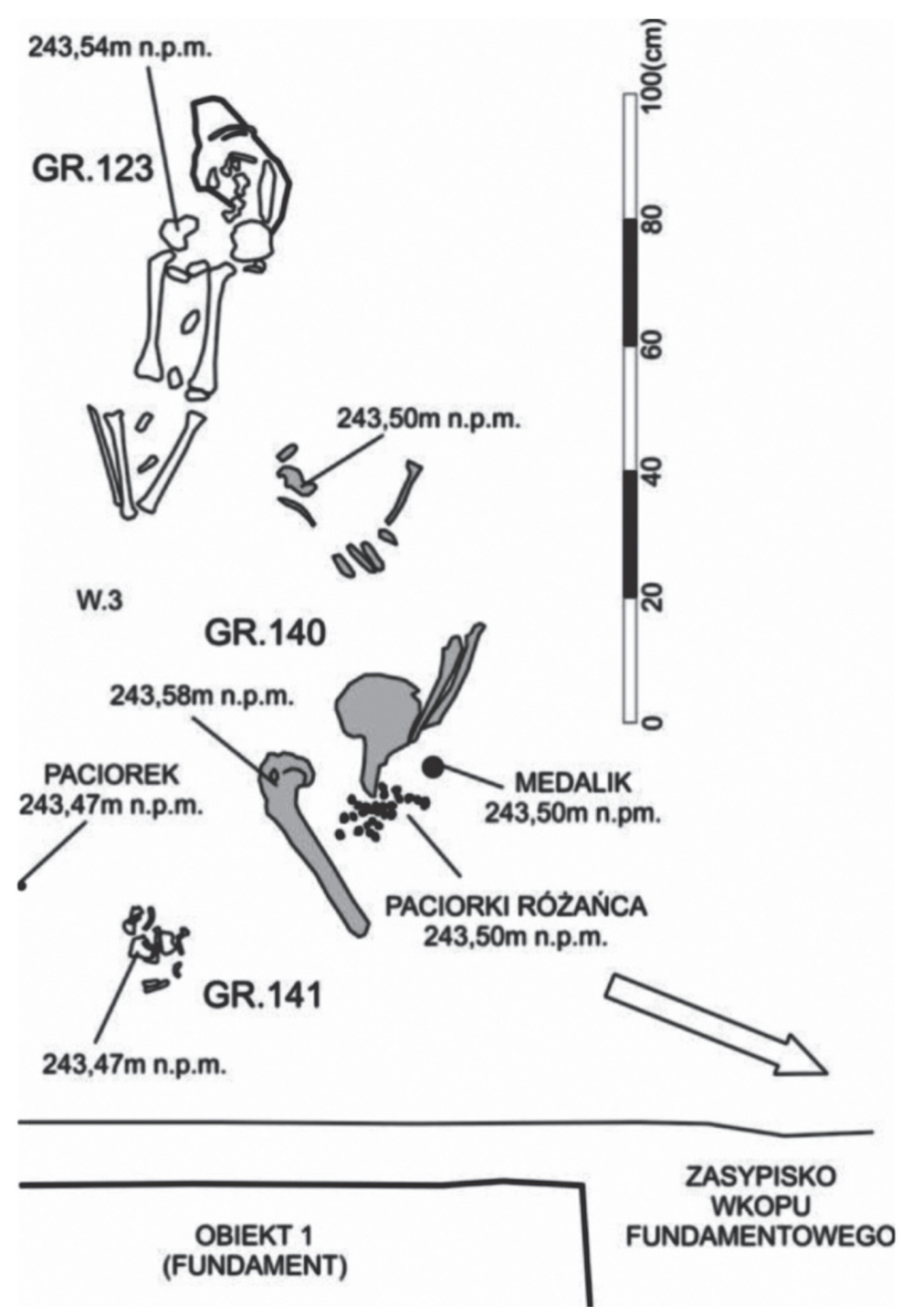

Tabl. III. Częstochowa Stare Miasto, stan. 49 (AZP 86-48/1), ul. Nadrzeczna/Jaskrowska. Plan grobu $140 \mathrm{z}$ medalikiem (rys. Z. Małek). 